Check for updates

Cite this: RSC Adv., 2017, 7, 48404

Received 4th September 2017

Accepted 9th October 2017

DOI: $10.1039 / c 7 r a 09825 a$

rsc.li/rsc-advances

\section{Synthesis, characterization and biological evaluation of formononetin derivatives as novel EGFR inhibitors via inhibiting growth, migration and inducing apoptosis in breast cancer cell line $\uparrow$}

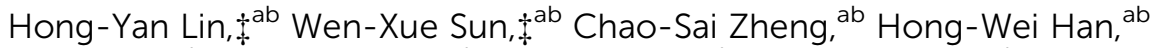 \\ Xue Wang, ${ }^{\text {ab }}$ Ya-Han Zhang, ${ }^{\text {ab }}$ Han-Yue Qiu, ${ }^{\text {ab }}$ Cheng-Yi Tang, ${ }^{\text {ab }}$ Jin-Liang Qi, ${ }^{\text {ab }}$ \\ Gui-Hua Lu, ${ }^{\text {ab }}$ Rong-Wu Yang, *ab Xiao-Ming Wang (D) *ab and Yong-Hua Yang (D) *ab
}

Over the past few decades, the human epidermal growth factor receptor (EGFR) has been established as an attractive target for non-small cell lung cancer (NSCLC) therapy. Nevertheless, the approved EGFR inhibitors, gefitinib or erlotinib have shown minimum clinical activity to breast cancer patients, who also highly expressed EGFR. In this study, we designed and synthesized a series of novel formononetin derivatives by reference to the binding mode of lapatinib to EGFR. In vitro EGFR and cell growth inhibition assay demonstrated that compound $4 \mathrm{v}$ exhibited the most potent anti-EGFR (IC $50=14.5 \mathrm{nM})$ and anti-proliferation activity $\left(\mathrm{IC}_{50}=5.44 \pm 1.28 \mu \mathrm{M}\right)$ against MDA-MB-231 cell line, which was comparable to that of lapatinib (EGFR, IC $50=5.6 \mathrm{nM}$; MDA-MB-231, IC $50=2.48 \pm 1.04 \mu \mathrm{M}$ ). Further biological experiment results demonstrated that $4 \mathrm{v}$ could effectively induce apoptosis, inhibit proliferation and migration in MDA-MB-231 cells through targeting EGFR and then blocking the downstream signaling pathways, EGFR/PI3K/Akt/Bad, EGFR/ERK and EGFR/PI3K/Akt/B-catenin, respectively. However, it had no significant influence on cell cycle distribution and the related proteins (Cyclin A, Cyclin D1, CDK4) expression. In vivo anti-tumor results also preliminarily confirmed the effectiveness of $4 v$ in tumor chemotherapy in mice and indicated its potential as a new EGFR inhibitor in the treatment of MDA-MB-231 malignant tumor.

\section{Introduction}

The epidermal growth factor receptor (EGFR) is a transmembrane protein, belonging to the family of tyrosine kinases and involved in cell proliferation and signal transduction. ${ }^{1}$ It has been confirmed that EGFR is highly or abnormally expressed in many solid tumors and is correlated to tumor cell proliferation, angiogenesis, tumor invasion, metastasis, and inhibition of apoptosis. ${ }^{2,3}$ Over-expression of EGFR is also crucial for the evolution of malignant tumors, such as glioma cell, kidney, lung, breast, prostate and pancreatic cancer. $^{4-6}$ The activation of EGFR phosphorylates its downstream signalling molecules PI3K and Akt, which are involved in

${ }^{a}$ State Key Laboratory of Pharmaceutical Biotechnology, NJU-NJFU Joint Institute of Plant Molecular Biology, Nanjing University, Nanjing, 210023, China. E-mail: Yangyh@nju.edu.cn; Wangxm07@nju.edu.cn; Robertyang@nju.edu.cn; Fax: +86-2589681381; Tel: +86-25-89681381

${ }^{b}$ Co-Innovation Center for Sustainable Forestry in Southern China, Nanjing Forestry University, Nanjing, 210037, China

$\dagger$ Electronic supplementary information (ESI) available. See DOI: $10.1039 / \mathrm{c} 7 \mathrm{ra09825a}$

\$ These two authors contribute equally to this article. cellular migration, apoptosis and mitogen-activated protein kinase signalling, Ras/Raf/MEK/ERK, as implicated in cell proliferation. ${ }^{7,8}$ It is well known that inhibition of EGFR kinasemediated signal is a well-established strategy for the treatment of advanced stage non-small cell lung cancer (NSCLC) and also correlated well with the proliferation and migration of aggressive triple negative breast cancer, MDA-MB-231.9,10

Studies have shown that triple-negative breast cancer was considered another potential indication for EGFR kinase inhibitors because they are not amenable to endocrine or HER-2 targeted therapies, while they highly-express EGFR kinase. ${ }^{\mathbf{1 0 , 1 1}}$ Some literatures have suggested a crucial role of EGFR in breast cancer proliferation and migration. However, inhibition of EGFR by gefitinib or erlotinib showed low efficacy in arresting tumor cell growth at the cell line level and minimum clinical activity.,12 Such extraordinary phenomenon always attracts us to explore the underlying mechanism and discover new potent EGFR inhibitors that are naturally derived chemicals as breast cancer therapeutics.

Natural products are a major source of drug discovery and cancer therapy. Formononetin (Fig. 1) is a bioactive isoflavone found in diverse Chinese medicine herbals, such as Amorpha 


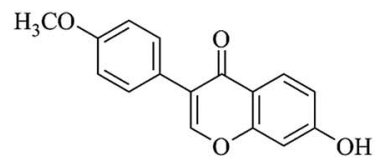

Formononetin<smiles>COc1ccc(-c2coc3cc(OCCCCSC(=S)N4CCN(C(=O)OC(C)(C)C)CC4)ccc3c2=O)cc1</smiles>

$8 \mathbf{i}$

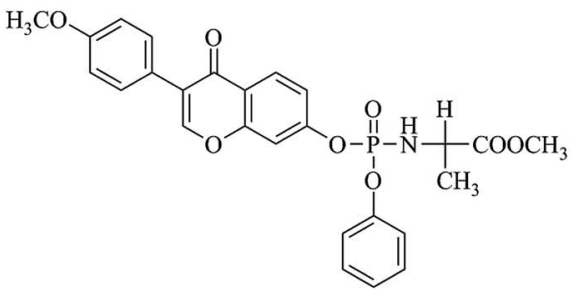

8d<smiles>COc1ccc(-c2coc3cc(OC4CCCCC4)ccc3c2=O)cc1N(CCCl)CCCl</smiles>

6n<smiles>O=c1cc(-c2ccccc2)oc2cc(O)cc(O)c12</smiles>

Chrysin

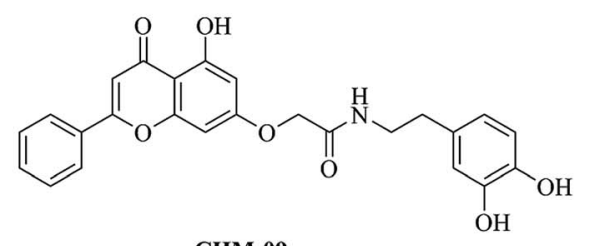

CHM-09

Fig. 1 Formononetin derivatives with anticancer activity.

fruticose ${ }^{13}$ Glycyrrhiza, ${ }^{13,14}$ Trifolium pretense, ${ }^{13,14}$ Astragalus membranaceus,${ }^{15}$ which belonging to the family of Leguminosae. It has attracted broad attention because of multiple pharmacological activities, such as anti-bacterial, ${ }^{16,17}$ anti-cancer, ${ }^{17}$ antioxidant, ${ }^{18}$ anti-diabetic ${ }^{19,20}$ and anti-hyperlipidemia. ${ }^{21}$ Currently, many formononetin analogues (Fig. 1) were designed as anticancer agents and explored the biological mechanism against various human cancer cell lines. As reported that formononetin can induce cell apoptosis via PI3K/AKT signaling pathway in human nasopharyngeal and cervical carcinoma cells. ${ }^{22}$ Formononetin-dithiocarbamate hybrids 8i could inhibit growth and migration of PC-3 cells via MAPK/Wnt signaling pathway and cause cell cycle arrest in G1 phase. ${ }^{23}$ While its 7-phosphoramidate derivative 8d and nitrogen-mustard derivative $\mathbf{6 n}$ could induce cell cycle arrest in $\mathrm{G} 2 / \mathrm{M}$ phase and cell apoptosis. ${ }^{24,25}$ In addition, Manupati et al. reported a chrysin analog CHM-09 which potentiated the mesenchymal-epithelial transition of breast cancer stem cells through inhibiting EGFR. ${ }^{10}$ In the light of previous studies, we reported here the designation of novel formononetin derivatives as potent anticancer agents through targeting EGFR and further investigation of their underlying biological mechanisms.

\section{Results and discussion}

\section{Chemistry}

In this study, we hypothesize that the design of synthetic derivatives of formononetin against EGFR with lapatinib as positive control may improve its anticancer efficacy. Before synthesis, a molecular screening process was performed by computer assist drug design (CADD) method. Molecular docking was conducted to calculate the binding energy (CDOCKER INTERACTION ENERGY in CDOCKER protocol in Discovery Studio 3.5) between compounds and EGFR complex structure (1XKK.pdb, downloaded from the PDB). Finally, 22 compounds were picked to continue assays subsequently and their binding energy were shown in Table S1 (ESI $\dagger$ ).

In view of the binding energy, $4 \mathbf{v}$ is the best one among them. For better understanding of the potential of $\mathbf{4 v}$, we further examined the interaction of $4 \mathbf{v}$ with EGFR (PDB code 1 XKK) with lapatinib as the positive control. All the amino acid residues which had interactions with lapatinib were exhibited and the results were depicted in Fig. 2A. In the binding model, lapatinib bound well to EGFR mainly via three hydrogen bonds with ARG 803, ASP 800 and PHE856, a $\pi$-cation bond with LYS 745 and a $\pi-\pi$ bond with PHE856. In the binding model of $4 \mathbf{v}$ with EGFR (Fig. 2C), there formed a hydrogen bond with MET 793, a $\pi$ cation bond with LYS 745, a $\pi$-anion bond with ASP 800 , a $\pi-\pi$ bond with PHE856 and a $\pi$-sigma bond with MET766 which are the main contributors for the effective combination between them. The 3D models of the interaction between lapatinib, $4 \mathbf{v}$ and EGFR were also depicted in Fig. 2B and D. For Fig. 2E, we further compared the structure and target combine similarity of $\mathbf{4 v}$ and lapatinib. The result demonstrated that 1c might be a potential EGFR inhibitor.

The synthetic routes of novel formononetin derivatives are outlined in Scheme 1, and structure of derivatives $4 \mathbf{a}-\mathbf{4 v}$ are shown in Table 1 . These compounds were obtained by three steps which were elucidated in the Experimental section. All of them are first reported and characterized by ${ }^{1} \mathrm{H}$ NMR, ${ }^{13} \mathrm{C}$ NMR, elemental analysis, melting test and mass spectroscopy, and results are in full accordance with their depicted structures. 
(A)

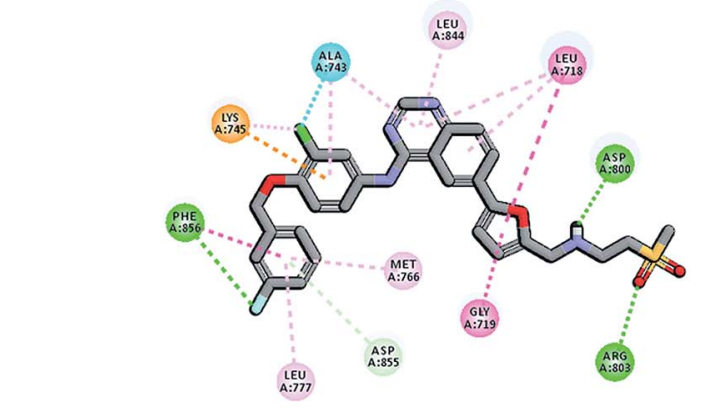

(B)

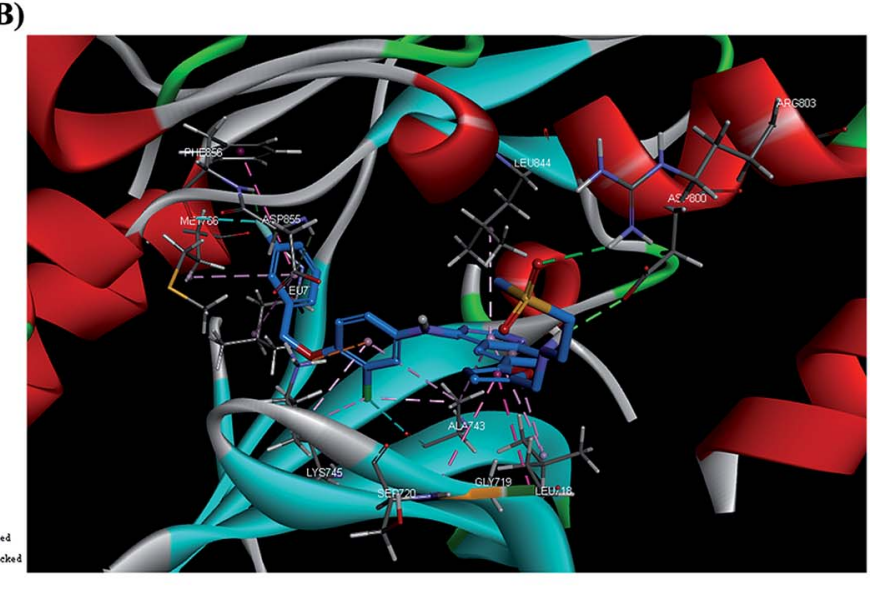

(D)

(C)
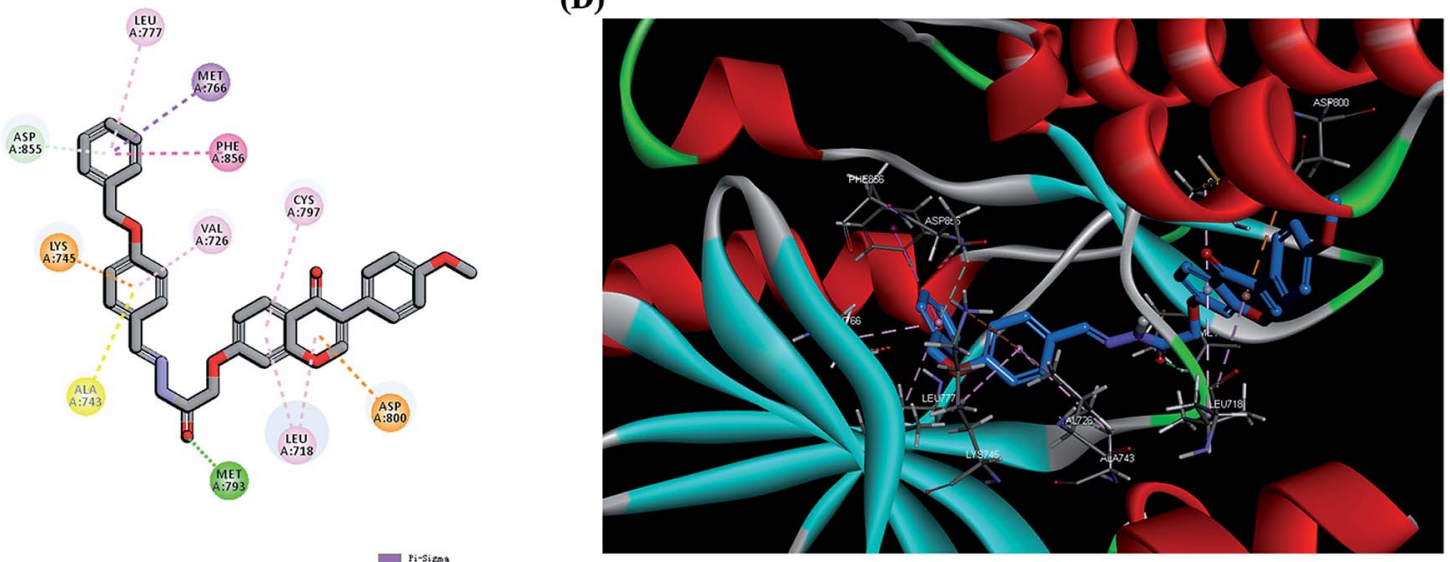

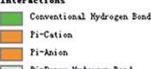

를

(E)

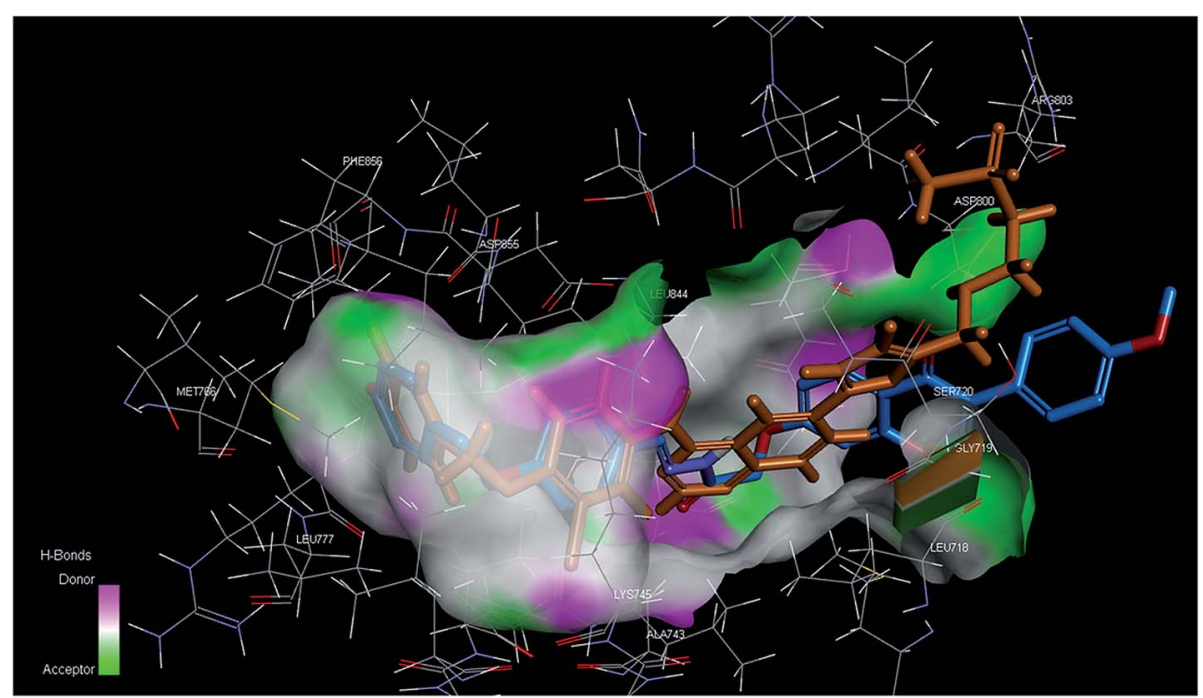

Fig. 2 Molecular docking analysis of $4 \mathrm{v}$ and lapatinib, showing proposed binding modes with EGFR (PDB code 1XKK). (A) Interactions of lapatinib with the amino acid residues at the binding pocket of EGFR (carbon atom, gray; oxygen atom, red; hydrogen atom, white; nitrogen atom, purple; chlorine atom, bright green; fluorine atom, light green; sulphur atom, orange). (B) Binding pose of lapatinib in the protein surface of EGFR (carbon atom, blue; oxygen atom, red; hydrogen atom, white; nitrogen atom, purple; chlorine atom, bright green; fluorine atom, sulphur atom, orange). Hydrogen bonds were displayed as green dashed lines. (C) Interactions of $4 \mathbf{v}$ with the amino acid residues at the binding pocket of EGFR (carbon atom, gray; oxygen atom, red; hydrogen atom, white; nitrogen atom, purple; sulphur atom, orange). (D) Binding pose of $4 \mathrm{v}$ in the protein surface of EGFR (carbon atom, blue; oxygen atom, red; hydrogen atom, white; nitrogen atom, purple; sulphur atom, orange). Hydrogen bond was displayed as green dashed lines. (E) 3D mode of the interaction between the compounds (lapatinib, brown; 4v, blue) and the EGFR binding site. The protein is represented by molecular surface. 


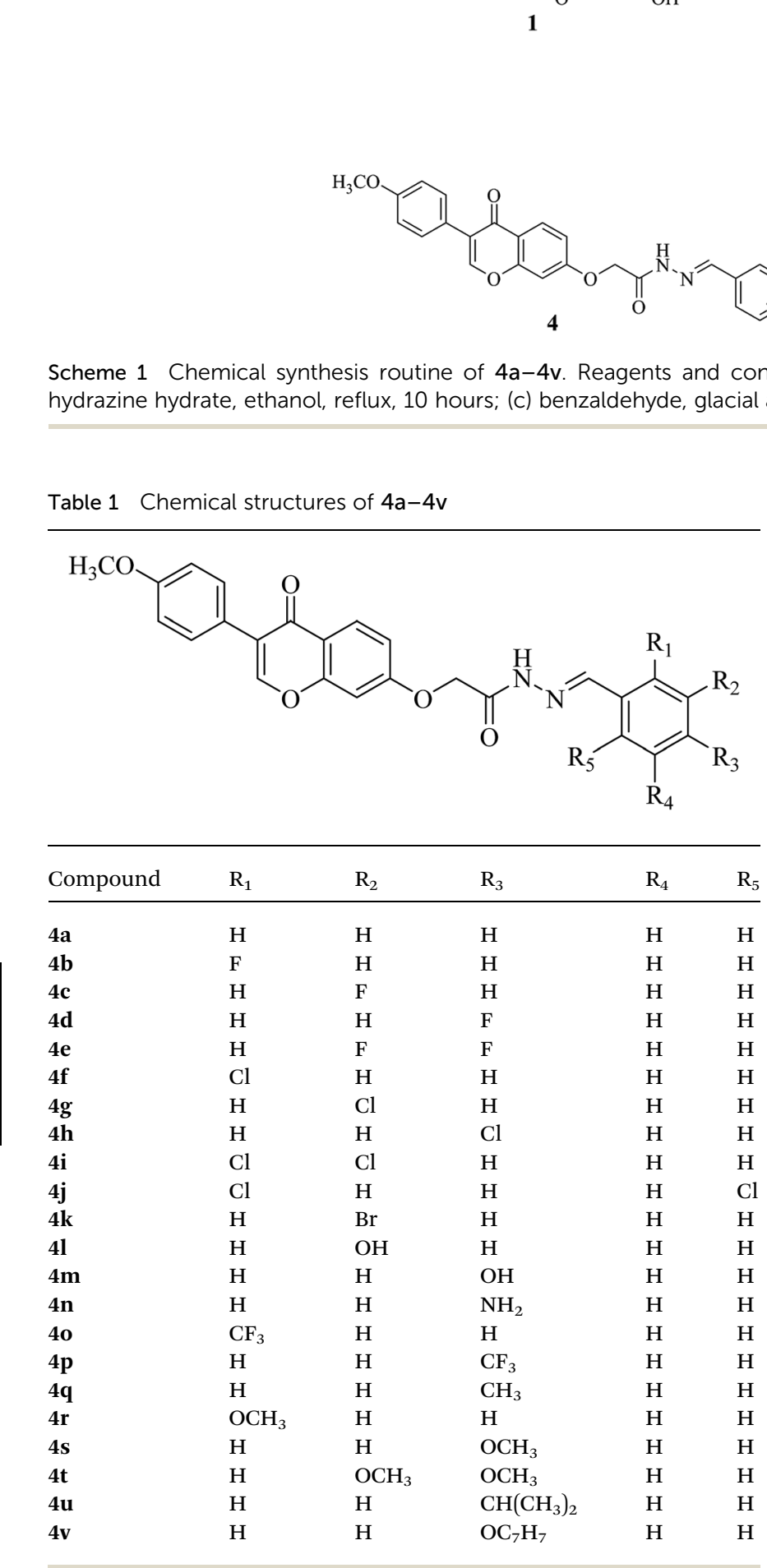

\section{Biological studies}

In order to screen out the optimal active compounds from all synthesized formononetin derivatives, a comparative study was carried out to evaluated their in vitro EGFR inhibition activities. As shown in Table 2, we clearly found that most of the tested compounds presented stronger EGFR inhibitory activity compared to formononetin itself. Especially, compound $\mathbf{4 v}$ was the most potent inhibitor of EGFR $\left(\mathrm{IC}_{50}=14.5 \mathrm{nM}\right.$ ), which was at least 10-fold stronger than formononetin $\left(\mathrm{IC}_{50}>150 \mathrm{nM}\right)$ and almost comparable to gefitinib $\left(\mathrm{IC}_{50}=6.2 \mathrm{nM}\right)$ and lapatinib $\left(\mathrm{IC}_{50}=5.6 \mathrm{nM}\right)$. Among them, compound $4 \mathrm{n}$ also showed potent EGFR inhibitory activity with an $\mathrm{IC}_{50}$ value of $20.6 \mathrm{nM}$. Generally, electron-donating group improved the enzymatic inhibitory activity more significantly than the electronwithdrawing group, especially when the substitution appeared at the R3-position of benzene ring of formononetin skeleton.

Table 2 The EGFR inhibitory activity of $4 a-4 v$, formononetin, gefitinib and lapatinib

\begin{tabular}{lll}
\hline & \multicolumn{2}{l}{ EGFR kinase } \\
\cline { 2 - 3 } Compound & \% inhibition at $150 \mathrm{nM}$ & \\
\hline $\mathbf{4 a}$ & 54.7 & $\mathrm{IC}_{50}(\mathrm{nM})$ \\
$\mathbf{4 b}$ & 51.6 & 120.4 \\
$\mathbf{4 c}$ & 33.5 & 131.6 \\
$\mathbf{4 d}$ & 70.3 & $>150$ \\
$\mathbf{4 e}$ & 68.4 & 52.6 \\
$\mathbf{4 f}$ & 52.3 & 66.2 \\
$\mathbf{4 g}$ & 50.2 & 142.2 \\
$\mathbf{4 h}$ & 72.8 & 146.3 \\
$\mathbf{4 i}$ & 60.1 & 30.7 \\
$\mathbf{4 j}$ & 58.5 & 98.4 \\
$\mathbf{4 k}$ & 56.2 & 105.8 \\
$\mathbf{4 1}$ & 50.9 & 112.5 \\
$\mathbf{4 m}$ & 73.5 & 139.5 \\
4n & 75.7 & 33.1 \\
$\mathbf{4 0}$ & 43.1 & 20.6 \\
4p & 66.8 & $>150$ \\
$\mathbf{4 q}$ & 70.4 & 48.9 \\
$\mathbf{4 r}$ & 62.9 & 30.4 \\
$\mathbf{4 s}$ & 68.3 & 56.4 \\
$\mathbf{4 t}$ & 80.6 & 40.6 \\
$\mathbf{4 u}$ & 76.9 & 47.8 \\
$\mathbf{4 v}$ & 87.3 & 35.5 \\
Formononetin & 26.4 & 14.5 \\
Gefitinib & 91.5 & $>150$ \\
Lapatinib & 94.2 & 6.2 \\
& & 5.6 \\
& &
\end{tabular}


Table 3 In vitro cell proliferation of compounds 4a-4v, formononetin and lapatinib against MCF-7, MDA-231 H460, H1650, L02 and VERO cell lines

\begin{tabular}{|c|c|c|c|c|c|c|}
\hline \multirow[b]{2}{*}{ Compound } & \multicolumn{6}{|l|}{$\mathrm{IC}_{50}(\mu \mathrm{M})$} \\
\hline & MCF-7 & MDA-231 & $\mathrm{H} 460$ & H1650 & L02 & VERO \\
\hline $4 b$ & $24.5 \pm 1.98$ & $20.7 \pm 1.62$ & $18.5 \pm 2.33$ & $38.6 \pm 3.56$ & $>100$ & $>100$ \\
\hline $4 c$ & $42.6 \pm 0.25$ & $33.6 \pm 1.83$ & $16.2 \pm 2.05$ & $17.8 \pm 2.13$ & $>100$ & $>100$ \\
\hline 4d & $21.5 \pm 0.91$ & $18.3 \pm 1.03$ & $16.5 \pm 1.22$ & $49.6 \pm 3.65$ & $65.8 \pm 4.62$ & $62.5 \pm 2.01$ \\
\hline $4 \mathrm{~g}$ & $41.5 \pm 2.01$ & $19.5 \pm 1.52$ & $16.5 \pm 5.49$ & $12.9 \pm 2.58$ & $>100$ & $>100$ \\
\hline $4 \mathrm{~h}$ & $17.8 \pm 1.64$ & $8.30 \pm 1.23$ & $8.02 \pm 1.02$ & $9.45 \pm 1.08$ & $>100$ & $29.3 \pm 1.94$ \\
\hline $4 i$ & $25.4 \pm 1.73$ & $16.3 \pm 1.24$ & $58.1 \pm 3.54$ & $19.7 \pm 2.27$ & $>100$ & $57.9 \pm 1.42$ \\
\hline $4 j$ & $25.7 \pm 1.53$ & $18.7 \pm 1.02$ & $19.6 \pm 1.55$ & $29.7 \pm 2.59$ & $>100$ & $78.8 \pm 2.23$ \\
\hline $4 \mathbf{k}$ & $21.5 \pm 0.63$ & $23.2 \pm 2.19$ & $22.7 \pm 2.28$ & $10.8 \pm 1.77$ & $>100$ & $36.5 \pm 3.14$ \\
\hline 41 & $21.1 \pm 2.76$ & $16.1 \pm 2.75$ & $16.3 \pm 1.99$ & $12.4 \pm 1.68$ & $>100$ & $>100$ \\
\hline $4 q$ & $17.2 \pm 1.93$ & $15.4 \pm 1.03$ & $16.7 \pm 2.49$ & $8.79 \pm 1.08$ & $>100$ & $>100$ \\
\hline $4 r$ & $15.9 \pm 3.42$ & $13.1 \pm 1.84$ & $24.6 \pm 3.39$ & $40.2 \pm 3.88$ & $>100$ & $55.7 \pm 2.05$ \\
\hline $4 s$ & $29.1 \pm 1.27$ & $10.1 \pm 1.55$ & $21.58 \pm 2.09$ & $15.3 \pm 2.31$ & $>100$ & $>100$ \\
\hline $4 t$ & $12.3 \pm 1.11$ & $8.42 \pm 1.21$ & $18.6 \pm 2.23$ & $24.3 \pm 1.89$ & $>100$ & $>100$ \\
\hline $4 \mathbf{u}$ & $25.9 \pm 1.94$ & $13.2 \pm 4.02$ & $14.3 \pm 1.84$ & $12.2 \pm 1.45$ & $>100$ & $>100$ \\
\hline $4 v$ & $11.5 \pm 1.52$ & $5.44 \pm 1.28$ & $6.36 \pm 1.55$ & $7.26 \pm 1.02$ & $>100$ & $95.2 \pm 4.72$ \\
\hline Formononetin & $36.4 \pm 3.01$ & $26.6 \pm 2.84$ & $27.8 \pm 2.22$ & $29.5 \pm 3.25$ & $82.6 \pm 5.73$ & $89.5 \pm 5.82$ \\
\hline Gefitinib & $13.5 \pm 3.08$ & $12.5 \pm 2.13$ & $3.02 \pm 0.89$ & $2.64 \pm 0.98$ & $35.2 \pm 3.08$ & $38.6 \pm 2.56$ \\
\hline Lapatinib & $7.10 \pm 2.81$ & $2.48 \pm 1.04$ & $1.22 \pm 0.35$ & $1.64 \pm 0.98$ & $42.5 \pm 2.59$ & $35.6 \pm 2.25$ \\
\hline
\end{tabular}

Then we further evaluated their anti-proliferation activities against four cancer cell lines, human breast cancer cells (MCF-7, MDA-MB-231), human lung carcinoma cells (H460, H1650), as well as two non-cancer cell lines, normal human liver cells (L02) and African green monkey kidney cell (VERO) by the cell based MTT assay. The results are summarized in Table 3 and expressed by the half maximal inhibitory concentration $\left(\mathrm{IC}_{50}\right)$ values. As shown in Table 3, all compounds showed good anti-proliferation activity against the cancer cells, and most of them even better than formononetin itself with the standard of $\mathrm{IC}_{50}$ values. To be specific, most compounds showed better anti-proliferation activity against MDA-MB-231 than MCF-7, which might because of the high expression of EGFR in the former. For MDA-MB-231 cell line, $4 \mathbf{h}\left(\mathrm{IC}_{50}=8.30 \pm 1.23\right), \mathbf{4 m}\left(\mathrm{IC}_{50}=9.35 \pm 1.02 \mu \mathrm{M}\right), \mathbf{4 n}\left(\mathrm{IC}_{50}=9.25\right.$ $\pm 1.05 \mu \mathrm{M}), 4 \mathrm{t}\left(\mathrm{IC}_{50}=8.42 \pm 1.21 \mu \mathrm{M}\right)$ and $4 \mathrm{v}\left(\mathrm{IC}_{50}=5.44 \pm 1.28\right.$ $\mu \mathrm{M})$ showed relatively better anti-proliferation activities than other compounds and their inhibitory efficacy against MDA-MB-231 were double stronger than against MCF-7 cell line $\left(4 \mathbf{h}, \mathrm{IC}_{50}=\right.$
(A)

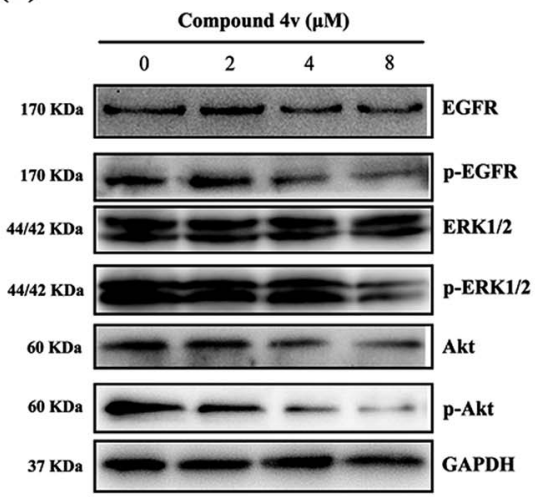

(B)

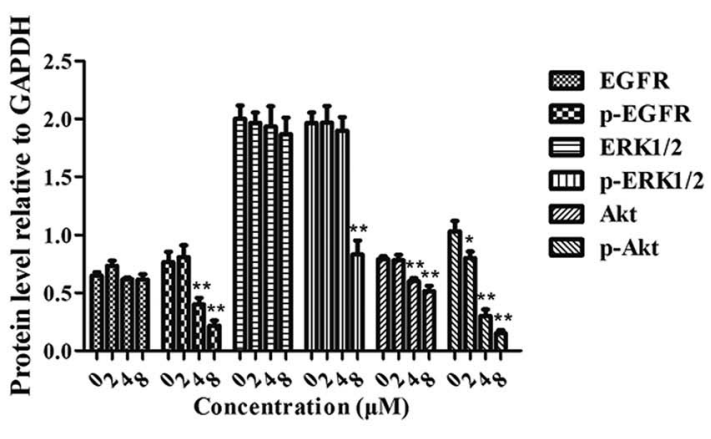

Fig. 3 The effects of $4 v$ on phosphorylation of EGFR and intracellular kinases in MDA-MB-231 cells. (A) Representative image of immunoblot analysis of EGFR signaling in MDA-MB-231 cells treated with $4 \mathrm{v}$. (B) Relative band intensity was determined by Image J software. GAPDH served as a loading control. Images are representative of three independent experiments. Data are means \pm S.E.M. from three independent experiments $(* P<0.05 ; * * P<0.01)$. 
$17.8 \pm 1.64 \mu \mathrm{M}, \mathbf{4 m}, \mathrm{IC}_{50}=20.9 \pm 2.24 \mu \mathrm{M}, \mathbf{4 n}, \mathrm{IC}_{50}=19.5 \pm 1.73$ $\mu \mathrm{M}, 4 \mathrm{t}, \mathrm{IC}_{50}=12.3 \pm 1.11 \mu \mathrm{M}$ and $\left.4 \mathrm{v}, \mathrm{IC}_{50}=11.5 \pm 1.52 \mu \mathrm{M}\right)$. Combined with the data of two human lung cancer cell lines, we clearly found that $\mathbf{4 h}$ and $\mathbf{4 v}$ showed much stronger inhibition effect than others, especially for $4 \mathbf{v}$ (MCF-7, $\mathrm{IC}_{50}=11.5 \pm 1.52 \mu \mathrm{M}$, MDA-MB-231, $\mathrm{IC}_{50}=5.44 \pm 1.28 \mu \mathrm{M}, \mathrm{H} 460, \mathrm{IC}_{50}=6.36 \pm 1.55 \mu \mathrm{M}$, $\mathrm{H} 1650, \mathrm{IC}_{50}=7.26 \pm 1.02 \mu \mathrm{M}$ ), which effect is almost comparable to that of lapatinib (MCF-7, $\mathrm{IC}_{50}=7.1 \pm 2.81 \mu \mathrm{M}$, MDA-MB-231, $\mathrm{IC}_{50}=2.48 \pm 1.04 \mu \mathrm{M}, \mathrm{H} 460, \mathrm{IC}_{50}=1.22 \pm 0.35 \mu \mathrm{M}, \mathrm{H} 1650$, $\left.\mathrm{IC}_{50}=1.64 \pm 0.98 \mu \mathrm{M}\right)$ and much better than the inhibitory effect of gefitinib against breast cancer cell lines (MCF-7, $\mathrm{IC}_{50}=13.5 \pm$ $\left.3.08 \mu \mathrm{M}, \mathrm{MDA}-\mathrm{MB}-231, \mathrm{IC}_{50}=12.5 \pm 2.13 \mu \mathrm{M}\right)$. Generally speaking, for comprehensive consideration anti-proliferation activities and the impact on $\log P$ (Table S2, ESI $\dagger$ ), $4 \mathbf{v}$ possessing 4-benzyloxy can be considered the optimal one in all newly synthetic compounds, and appeared to be a more efficient inhibitor of MDA-MB-231 cell viability $\left(\mathrm{IC}_{50}=5.44 \pm 1.28 \mu \mathrm{M}\right)$ when compared with formononetin $\left(\mathrm{IC}_{50}=26.6 \pm 2.84 \mu \mathrm{M}\right)$.

EGFR activation has been associated with multiple biological processes in cancer progression, such as cell proliferation,
(A)

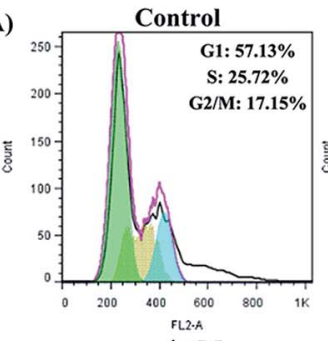

$4 \mu \mathrm{M}$

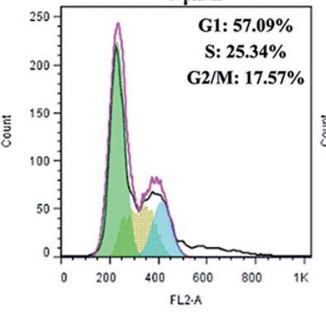

(C)

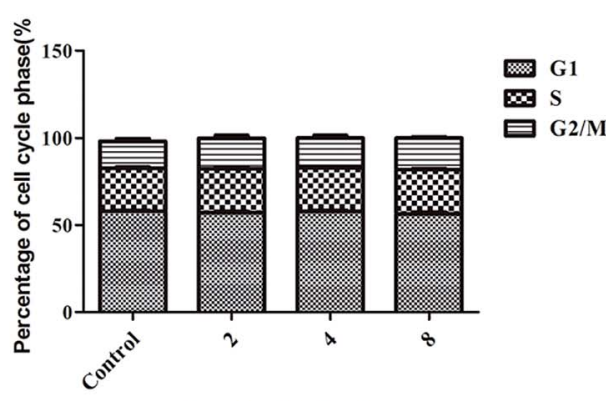

Concentration $(\mu \mathrm{M})$

(E)

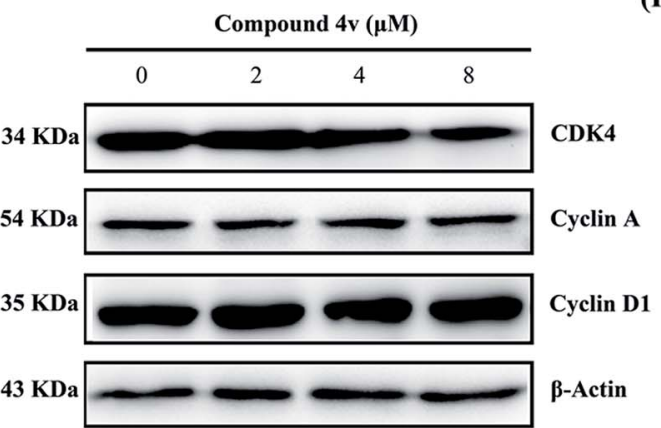

$8 \mu \mathrm{M}$

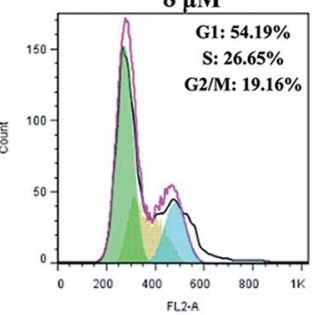

(B)
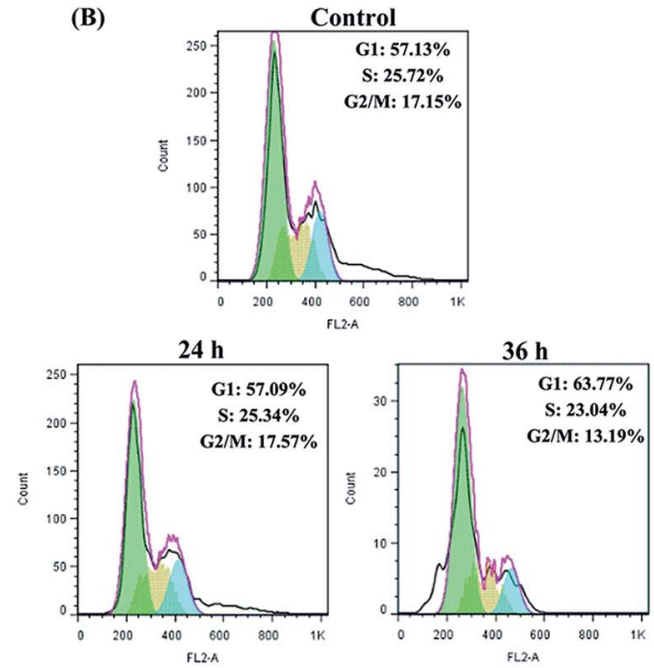

(D)

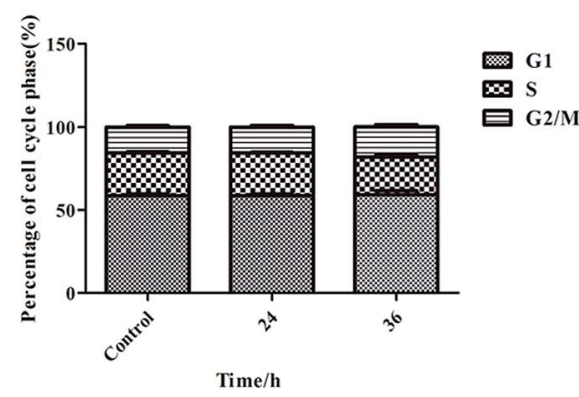

(F)

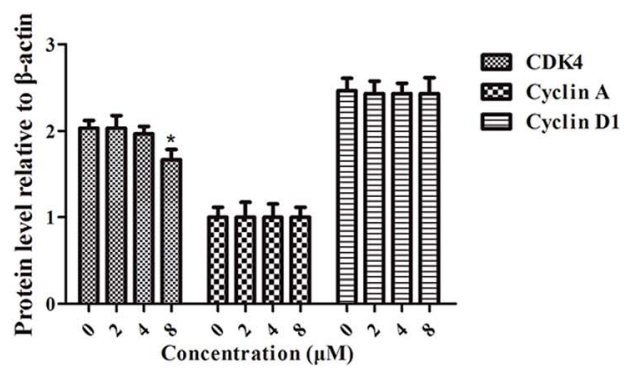

Fig. 4 The effects of $4 v$ on cell cycle distribution in MDA-MB-231 cells. (A) Cell cycle analysis of MDA-MB-231 cells treated with different concentrations of $4 \mathrm{v}$. (B) Cell cycle analysis of MDA-MB-231 cells treated with 4v for different time (G1 phase, green; S phase, yellow and G2/M phase, blue). (C) Statistic analysis of dose-dependent assay. (D) Statistic analysis of time-dependent assay. (E) Representative image of immunoblot analysis of cell cycle related proteins in MDA-MB-231 cells treated with 4v. (F) Relative band intensity was determined by Image J software. $\beta$-Actin served as a loading control. Images are representative of three independent experiments. Data are means \pm S.E.M. from three independent experiments $(* P<0.05 ; * * P<0.01)$. 
migration and metastasis through different signaling pathways. $^{26}$ To investigate the effect of $\mathbf{4 v}$ on signal transduction mechanism, we performed immunoblot analysis of EGFR and its downstream signaling pathways: extracellular signal regulated kinase (ERK) and Akt. As shown in Fig. 3, MDA-MB-231 cells that express high EGFR were treated with increasing concentrations of $\mathbf{4 v}$ and demonstrated a dose-dependent decrease in phosphorylation of EGFR, ERK and Akt.

To further substantiate the anti-proliferative effect of $\mathbf{4 v}$ on MDA-MB-231 cells, we evaluated its impact on the cell cycle arrest. As illustrated in Fig. 4A-D, $4 \mathbf{v}$ treated cells demonstrated no obvious cell cycle arrest versus the control groups. Then, we performed immunoblot analysis of cell cycle related proteins, Cyclin A, Cyclin D1 and CDK4. And the results shown in Fig. 4E and $\mathrm{F}$ indicated that the expression of the cell cycle related proteins in MDA-MB-231 cells did not increase after treated with compound $\mathbf{4 v}$.

The transmembrane potential $\left(\Delta \Psi_{\mathrm{m}}\right)$ is an important parameter for mitochondrial functionality and its dissipation means the involvement of mitochondria in early apoptosis. ${ }^{27}$ As shown in Fig. 5, microscopy revealed that in untreated MDA-
MB-231 cells, well-polarized mitochondria were marked by red fluorescent staining. After treated with 2 or $4 \mu \mathrm{M}$ of $4 \mathbf{v}$, this pattern was replaced by green fluorescence in MDA-MB-231 cells. CCCP was used as the positive control here. Additionally, flow cytometry results also showed that untreated cells with well-polarized, red-emitting mitochondria localized in the upper region of the plot. Cells exposed to $\mathbf{4 v}$ for 12 hours underwent a progressive loss of red fluorescence, indicated by a downward in $\mathbf{4 v}$ treated groups. The ratio of cells with high membrane potential decreased from $85.2 \%$ to $80.8 \%$ after exposed to $2 \mu \mathrm{M} \mathbf{4 v}$ for 12 hours and even decreased to $56.8 \%$ in $4 \mu \mathrm{M} 4 \mathbf{v}$ treated group. Likewise, the loss of mitochondrial potential in MDA-MB-231 cells caused by $\mathbf{4 v}$ also showed timedependent manner.

Based on the above results, we also evaluated the apoptotic populations of MDA-MB-231 cells treated with $4 \mathbf{v}$ using flow cytometry analysis. As shown in Fig. 6A, cells treated with increasing concentrations of $\mathbf{4 v}$ and demonstrated a dosedependent increase in apoptotic populations. In addition, cells treated with $\mathbf{4 v}$ for increasing time also demonstrated a time-dependent manner in apoptotic populations and

(A)
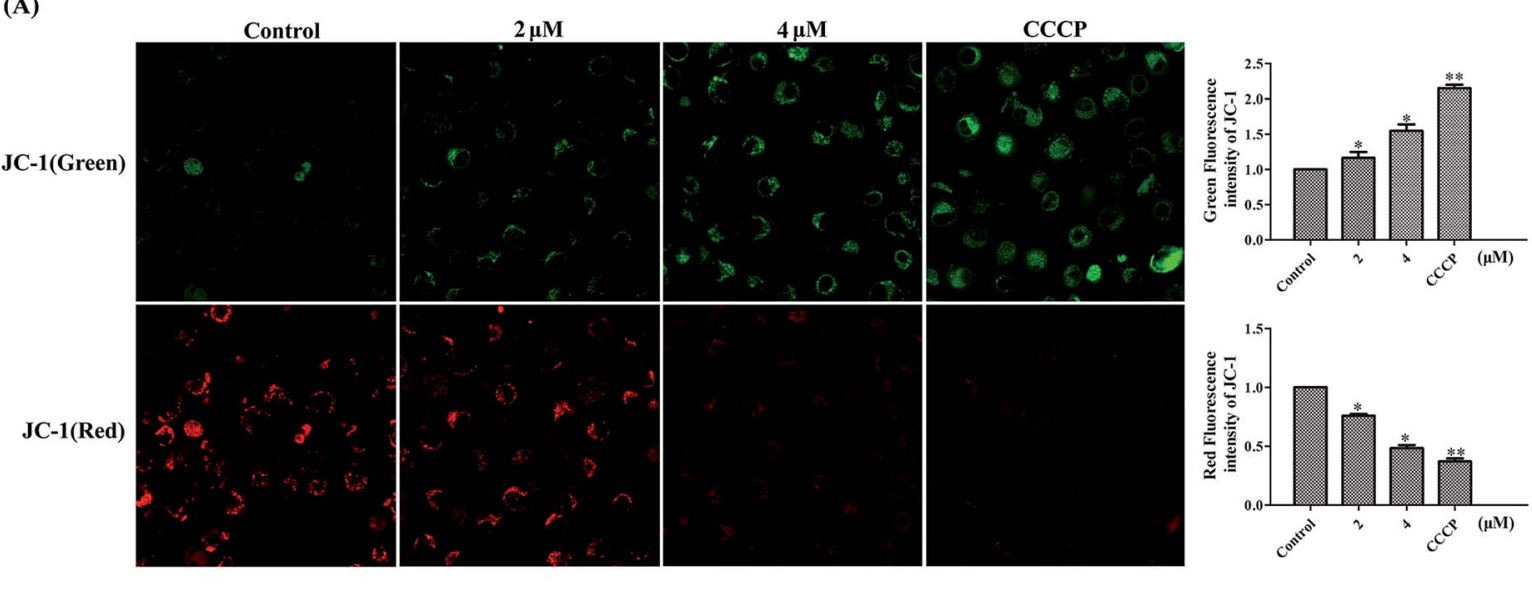

(B)
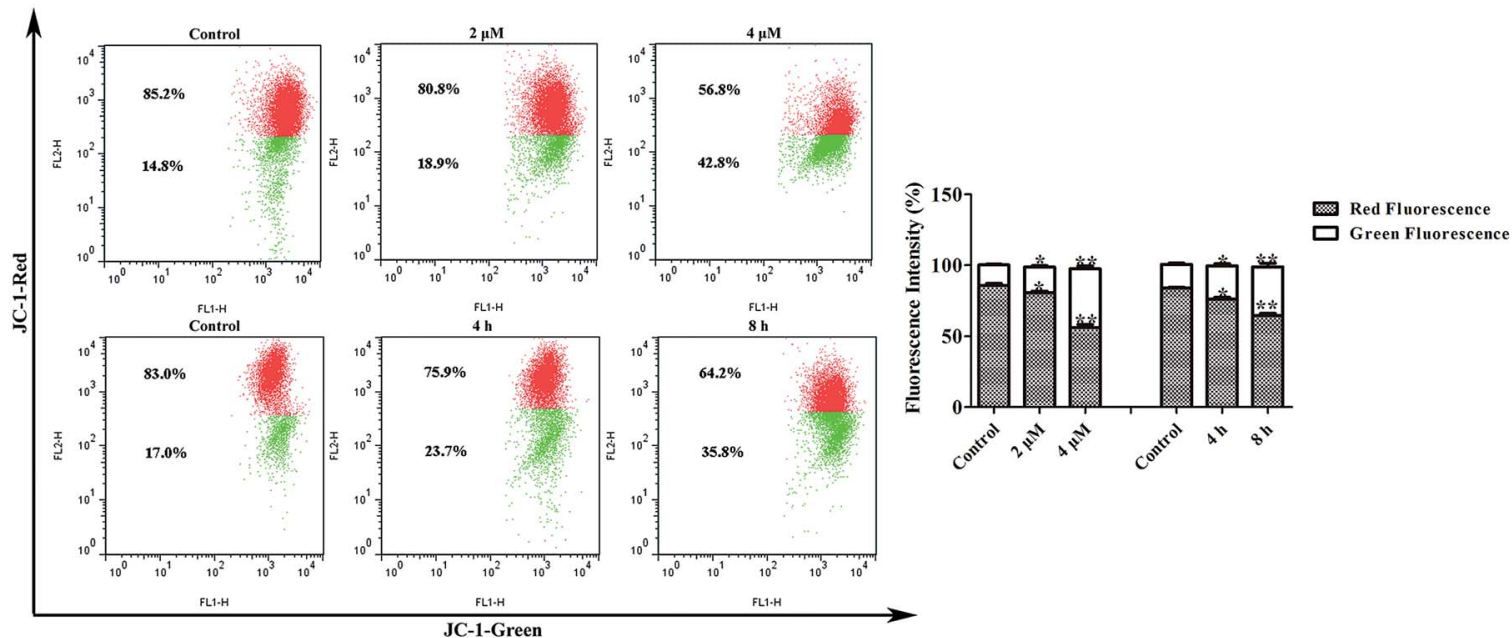

Fig. $54 \mathrm{v}$ decreased the mitochondrial membrane potential of MDA-MB-231 cells. (A) Cytofluorimetric analysis of mitochondrial membrane potential $\left(\Delta \Psi_{m}\right)$ by JC-1 staining. (B) Flow cytometry analysis of MDA-MB-231 cells with high $\Delta \Psi_{m}(\%)$ by JC-1 staining. Each point represents the mean \pm S.E.M. from three replicates $(* P<0.05, * * P<0.01)$. 
(A)

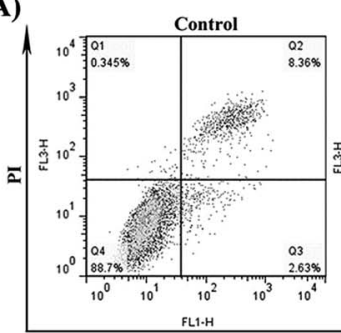

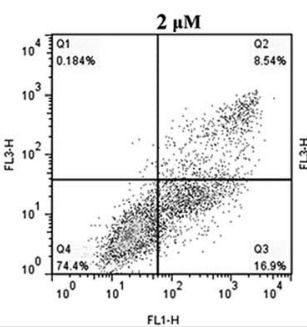
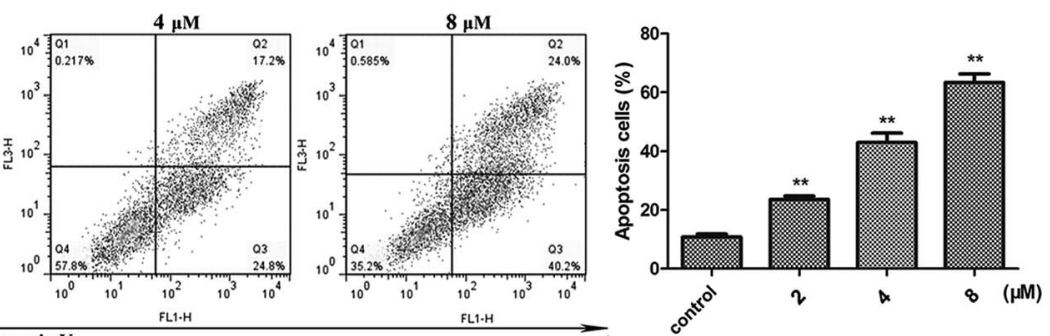

(B)
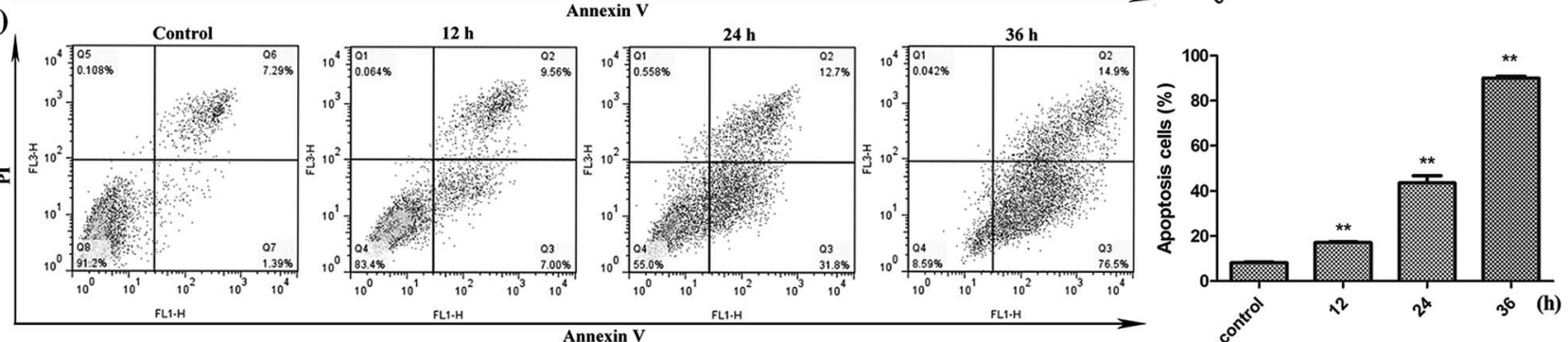

(C)

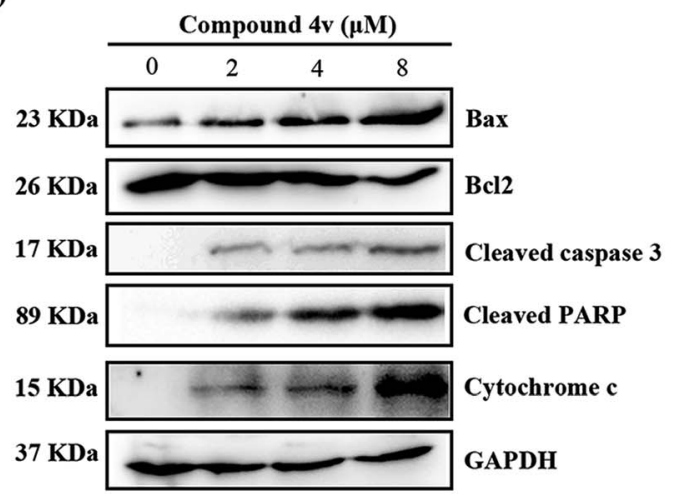

(D)



Fig. 6 The effects of $4 \mathrm{v}$ on cell apoptosis in MDA-MB-231 cells. (A) Annexin V/PI double staining and cytometry analysis of $4 \mathrm{v}$-induced apoptosis in a dose-dependent manner. (B) Annexin V/PI double staining and cytometry analysis of $4 \mathrm{v}$-induced apoptosis in a time-dependent manner. (C) Western blot analyses of apoptosis-related proteins (Bax, Bcl2, cleaved caspase 3, cleaved PARP and cytochrome c) separated by SDS-PAGE. (D) Relative band intensity was determined by Image $\mathrm{J}$ software. GAPDH served as a loading control. Images are representative of three independent experiments. Data are means \pm S.E.M. from three independent experiments ( $* P<0.05 ; * * P<0.01$ ).

a significant high percentage (approximately 90.4\%) of apoptotic cells were observed in 36 hours-treated cells compared to vehicle control (Fig. 6B). This observation was further substantiated by concomitant increased expression of pro-apoptotic proteins, Bax, cytochrome c, cleaved caspase-3, cleaved PARP and decreased expression of anti-apoptotic Bcl2 after exposure to $4 \mathbf{v}$ (Fig. 6C).

Tumor cell migration has been identified as one hallmark of malignant tumor progression, particularly for the establishment of lethal secondary metastases at distant organs. To investigate whether $4 \mathbf{v}$ could inhibit the migratory capacity of MDA-MB-231 cells, the conventional in vitro wound healing assay was also conducted. As shown in Fig. 7A and B, the control group cells gradually occupied the cell-free space within the channel over time and the cells almost fill the channel after 48 hours. Whereas, cells migration capacity of $\mathbf{4 v}$-treated group was greatly inhibited and the inhibition was dose-dependent. The Wnt signaling pathway is crucial for multiple cellular processes including cell proliferation and migration. Once activated, $\beta$-catenin disassembles from complex comprised of Axin, APC and GSK3 $\beta$ and translocates into nuclear. Then it interacts with TCF4 which promotes the downstream target gene transcription. On the basis of the wound healing assay, we subsequently investigated the influence of $\mathbf{4} \mathbf{v}$ on Wnt signaling pathway in MDA-MB-231 cells. Western bolt analysis results shown in Fig. 7C indicated that treatment of MDA-MB-231 cells with $4 \mathbf{v}$ resulted in the decrease expression of $\beta$-catenin and the increase expression of Axin-2 in dose-dependent manners. These results collectively suggested that $4 \mathbf{v}$ might inhibit migration of MDA-MB-231 cells via Wnt signaling pathway.

To evaluate the anti-tumor effects of $\mathbf{4 v}$ in vivo, we subcutaneously inoculated MDA-MB-231 cells in to the right flank of female nude mice. Two weeks later, all the mice got visible tumors. The mice were randomized into 3 groups, vehicle (olive oil), $4 \mathbf{v}\left(5 \mathrm{mg} \mathrm{kg}^{-1}\right)$ and positive control (gefitinib, $5 \mathrm{mg} \mathrm{kg}^{-1}$; lapatinib, $5 \mathrm{mg} \mathrm{kg}^{-1}$ ). As shown in Fig. 8A, the administration of 4v greatly inhibited the tumor growth compared with the vehicle group and the inhibition effect was similar to that of 
(A)

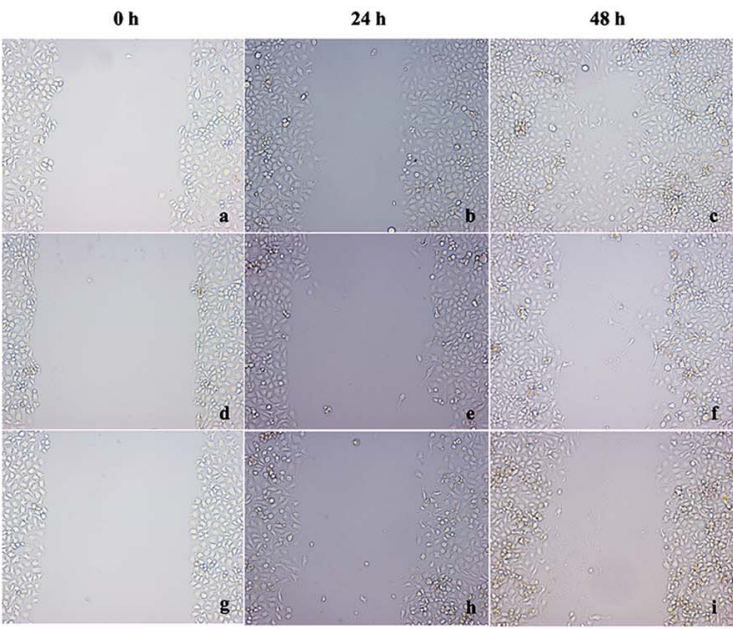

(C)

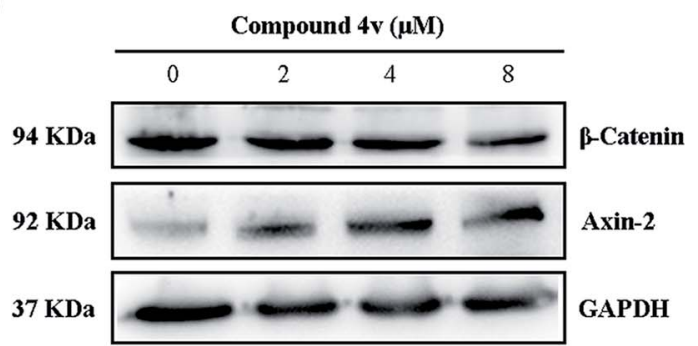

(B)
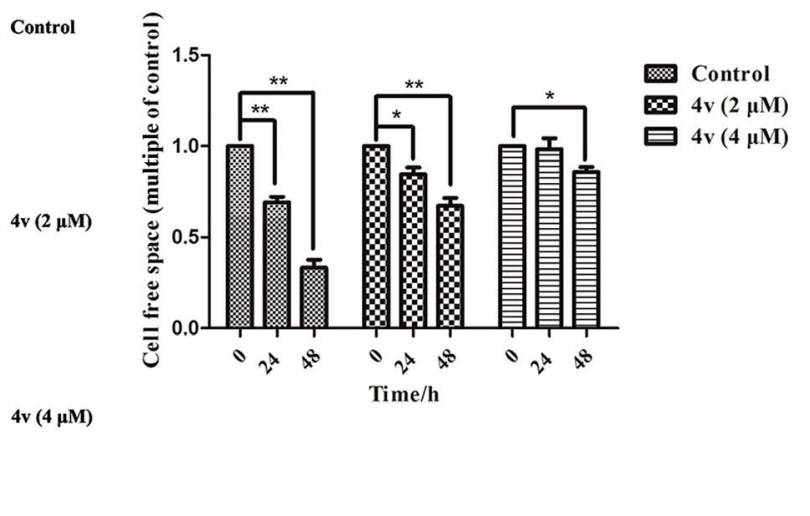

(D)

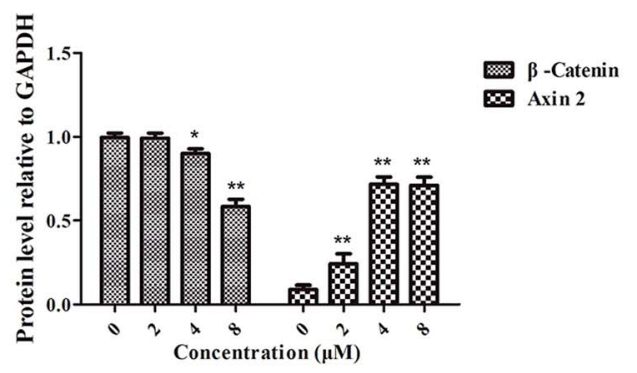

Fig. 7 The effects of $4 v$ on cell migration in MDA-MB-231 cells. (A) Cell migration was detected by the wound scrape assay. Representative images of cell migration in the wound scrape model at 0,24 and 48 hours are shown. (B) Statistical analysis of the wound scrape assay. (C) Western blot analyses of Wnt signaling pathway proteins ( $\beta$-catenin and Axin-2) separated by SDS-PAGE. (D) Relative band intensity was determined by Image $\mathrm{J}$ software. GAPDH served as a loading control. Images are representative of three independent experiments. The data represent the means \pm S.E.M. of three independent experiments. $* P<0.05, * * P<0.01$.

lapatinib, while the traditional EGFR inhibitor gefitinib showed extremely low therapeutic efficiency on MDA-MB-231 cells. After the last time of treatment on day 21 , the average weight of tumors from $\mathbf{4 v}$-treated mice was nearly 2-fold less than the olive oil treated group (Fig. 8C). Meanwhile, $4 \mathbf{v}$ has no significant influence on the body weight of the mice (Fig. 8B).

\section{Experimental}

\section{General information and materials}

Formononetin (purity $\geq 99 \%$ ), ethyl bromoacetate, hydrazine hydrate, a series of benzaldehyde with different substituents, acetic acid, acetone, ethanol, etc. According to experimental conditions, all reagents used were of analytical reagent grade (AR) except ethanol which was purified and purchased from Nanjing Chemical Reagent Co. Ltd. (Nanjing, China). Gefitinib (purity $\geq 99 \%$ ) and lapatinib (purity $\geq 99 \%$ ) were purchased from J\&K Scientific Ltd. (Shanghai, China). ${ }^{1} \mathrm{H}$ NMR and ${ }^{13} \mathrm{C}$ NMR spectra of all intermediate and final products were recorded on a DRX 600 spectrometer and DMSO-d6 as solvent. Chemical shifts (d) for ${ }^{1} \mathrm{H}$ NMR and ${ }^{13} \mathrm{C}$ NMR spectra were reported in ppm (d). The ESI-MS spectra were obtained on a Mariner Biospectrometry Workstation (ESI-TOF) mass spectrometer. Melting points of products were determined using a XT4 MP Apparatus (Taike Corp., Beijing, China) and uncorrected. TLC was carried out on the glass-backed silica gel sheets (silica gel $60 \AA$ GF254) and visualized in UV light (254 nm).

Cell culture reagents were purchased from Gibco Life Technology (Grand Island, NY, USA). MTT, PMSF, and RIPA lysis buffer (\#P0013B) were purchased from Beyotime Institute of Biotechnology (Haimen, China). Cell Cycle Detection Kit and Annexin V-FITC/PI apoptosis detection kit were purchased from KeyGEN Biotech Co. Ltd (Nanjing, China). Mitochondrial membrane potential assay kit with JC-1 was purchased from Beyotime Biotech Co. Ltd (Haimen, China). BCA protein assay kit (\#23227) was purchased from Pierce (Rockford, IL, USA). PVDF membranes were purchased from Biosharp (Hefei, China). Anti-Axin-2 (20540-1-AP) was purchased from Proteintech (Wuhan, China); anti-cleaved PARP-1 (\#sc-56196) was purchased from Santa Cruz Biotechnology Inc. (Dallas, Texas, USA). Anti-EGFR (WL0682a), anti-ERK (WL01864), anti-p-ERK (WLP1512), anti-Akt (WL0003b), anti-p-Akt (WLP001a), antiCDK4 (WL02143), anti-Cyclin A (WL01753), anti-Cyclin D1 (WL01435a), anti- $\beta$-Actin (WL0002c), anti-Bax (WL01637), antiBcl2 (WL01556), anti-cleaved caspase-3 (WL01992), anticytochrome c (WL01571) and anti- $\beta$-catenin (WL0962a) were purchased from Wanlei Biotech Co. Ltd (Shenyang, China). GAPDH antibody (\#E1A7021) and secondary antibody (anti- 
(A)

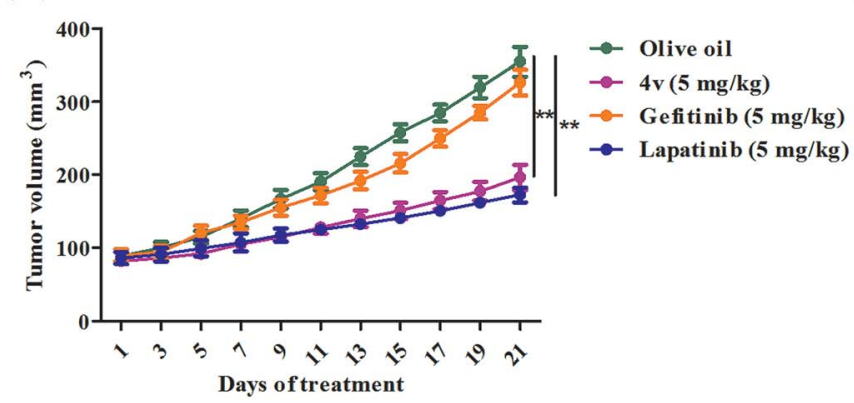

(B)

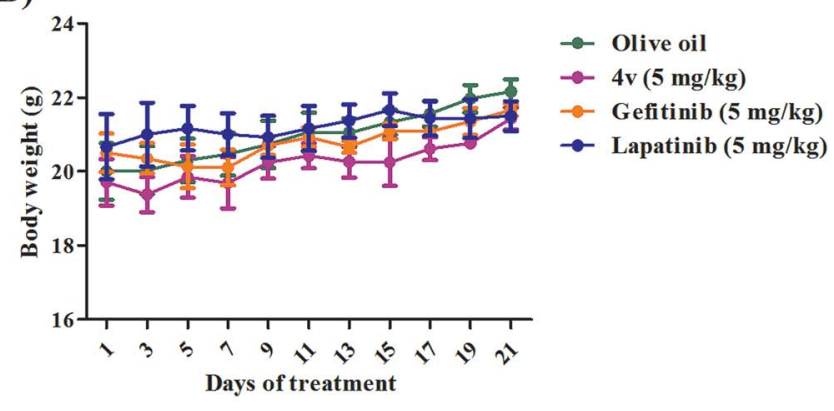

(C)

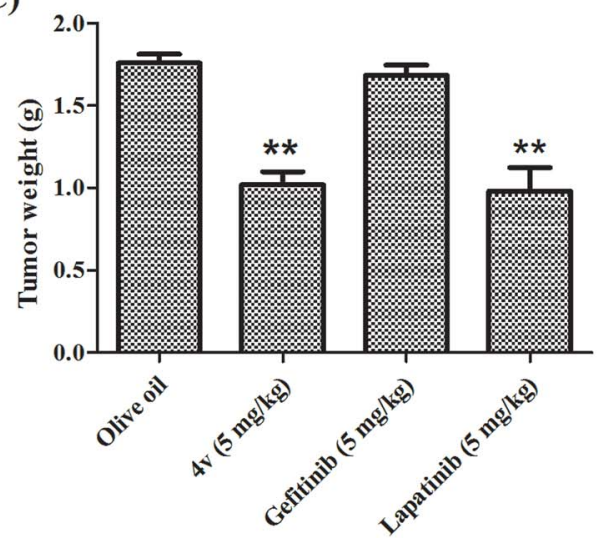

Fig. $84 \mathrm{v}$ suppresses tumor growth of MDA-MB-231 xenografts in nude mice. (A) Tumor volumes of the mice. (B) Body weight of the mice. (C) Tumor weight of mice. Data are the mean \pm S.E.M. of 8 mice per group $(* P<0.05 ; * * P<0.01$ versus vehicle (olive oil)).

mouse or anti-rabbit IgG) (\#E1WP319 or \#E1WP318) were purchased from Enogene (Nanjing, China). ECL Kit (\#34077) were purchased from Thermo Scientific (USA).

\section{General procedure for preparation of compound 2}

A mixture of formononetin (0.04 mol, $11.44 \mathrm{~g})$ and potassium carbonate ( $0.08 \mathrm{~mol}, 22.48 \mathrm{~g})$ were stirred in acetone under the condition of reflux at $60{ }^{\circ} \mathrm{C}$ for 3 hours to get dissolved and clarified. Meanwhile, proportionable ethyl bromoacetate (0.04 mol, $4.9 \mathrm{~g}$ ) was prepared which dissolved in appropriate acetone and added to the system dropwise to react another 10 hours. And then reaction system was filtered in hot to obtain filtrate. When the filtrate tended to be cooling, a large amount of compound 2 separated out and washed with petroleum ether, $1 \%$ sodium hydroxide and distilled water successively. The product was dried in the oven weighing $9.97 \mathrm{~g}$ (87\%). White powder, yield 95\%; mp: 188.5-189.3 ${ }^{\circ} \mathrm{C} ;{ }^{1} \mathrm{H}$ NMR $(300 \mathrm{MHz}$, $\left.\mathrm{CDCl}_{3}\right) \delta 8.24(\mathrm{~d}, J=8.9 \mathrm{~Hz}, 1 \mathrm{H}), 7.92(\mathrm{~s}, 1 \mathrm{H}), 7.53-7.46(\mathrm{~m}, 2 \mathrm{H})$, $7.03(\mathrm{dd}, J=8.9,2.4 \mathrm{~Hz}, 1 \mathrm{H}), 7.00-6.94(\mathrm{~m}, 2 \mathrm{H}), 6.84(\mathrm{~d}, J=$ $2.4 \mathrm{~Hz}, 1 \mathrm{H}), 4.73(\mathrm{~s}, 2 \mathrm{H}), 4.31$ (q, $J=7.1 \mathrm{~Hz}, 2 \mathrm{H}), 3.84(\mathrm{~s}, 3 \mathrm{H})$, 1.25 (dd, $J=8.4,5.6 \mathrm{~Hz}, 3 \mathrm{H})$. ESI-TOF, calcd for $\mathrm{C}_{19} \mathrm{H}_{16} \mathrm{O}_{6}([\mathrm{M}+$ $\mathrm{Na}]^{+}$) 363.33, found 363.09. Anal. calcd for $\mathrm{C}_{19} \mathrm{H}_{16} \mathrm{O}_{6}: \mathrm{C}, 67.06$; H, 4.74; O, 28.21. Found: C, 66.87; H, 4.92; O, 28.29.

\section{General procedure for preparation of compound 3}

Compound 2 (0.025 mol, $8.85 \mathrm{~g}$ ) was added to a clean roundbottom flask which contained $30-40 \mathrm{~mL}$ of ethanol. The reaction mixture was stirred under the condition of reflux at $80{ }^{\circ} \mathrm{C}$. Hydrazine hydrate $(0.075 \mathrm{~mol}, 3.9 \mathrm{~g})$ was added and stirred for a further 10 hours with the reaction system getting clarified gradually. While stirring, the product was checked with TLC continually to choose the right point in time to stop the reaction. After the system temperature cooling to room temperature, the compound $\mathbf{3}$ which is white was isolated by filtration when precipitated. The product was dried in the oven weighing $7.45 \mathrm{~g}$ (84\%). White powder, yield 87\%; mp: 200.4$201.7{ }^{\circ} \mathrm{C} ;{ }^{1} \mathrm{H}$ NMR $(300 \mathrm{MHz}, \mathrm{DMSO}) \delta 9.32(\mathrm{~s}, 1 \mathrm{H}), 7.78(\mathrm{~d}, J=$ $70.9 \mathrm{~Hz}, 1 \mathrm{H}), 7.18$ (d, $J=8.2 \mathrm{~Hz}, 2 \mathrm{H}), 7.07-6.68(\mathrm{~m}, 3 \mathrm{H}), 6.43$ (d, $J=34.4 \mathrm{~Hz}, 2 \mathrm{H}), 4.42(\mathrm{~s}, 2 \mathrm{H}), 4.31(\mathrm{~s}, 2 \mathrm{H}), 3.71$ (s, 3H). ESI-TOF, calcd for $\mathrm{C}_{17} \mathrm{H}_{14} \mathrm{~N}_{2} \mathrm{O}_{5}\left([\mathrm{M}+\mathrm{Na}]^{+}\right)$349.31, found 349.09. Anal. calcd for $\mathrm{C}_{17} \mathrm{H}_{14} \mathrm{~N}_{2} \mathrm{O}_{5}$ : C, 62.57; H, 4.32; N, 8.59; O, 24.52. Found: C, 61.94; H, 4.41; N, 8.66; O, 24.59.

\section{General procedure for preparation of compounds $4 a-4 v$}

Compounds $\mathbf{4 a}-\mathbf{4 v}$ were synthesized by reacting the compound $3(0.0008 \mathrm{~mol})$ with the different substituted ethyl benzaldehyde $(0.0008 \mathrm{~mol})$ in a Schiff base condensation reaction. The reaction was stirred at $80{ }^{\circ} \mathrm{C}$ for 8 hours in the presence of a bit of glacial acetic acid (4-8 drops) in ethanol. The compounds $\mathbf{4 a - 4 v}$ were obtained by filtering after precipitation and all structure shown in Table 1.

(Z)- $N^{\prime}$-Benzylidene-2-((3-(4-methoxyphenyl)-4-oxo-4H-chromen7-yl)oxy)-acetohydrazide (4a). White powder, yield 75\%; mp: 250.5-252.3 ${ }^{\circ} \mathrm{C}$; 96.5\% purity (HPLC); ${ }^{1} \mathrm{H}$ NMR (300 MHz, DMSO) 
$\delta 11.60(\mathrm{~d}, J=7.3 \mathrm{~Hz}, 1 \mathrm{H},-\mathrm{CH}=\mathrm{N}), 8.32-8.00(\mathrm{~m}, 1 \mathrm{H}, \mathrm{Ar}-\mathrm{H}), 7.90$ 7.62 (m, 3H, N-NH, Ar-H), 7.44 (d, J=3.6 Hz, 3H, Ar-H), 7.27-7.11 $(\mathrm{m}, 2 \mathrm{H}, \mathrm{Ar}-\mathrm{H}), 7.03$ (t, $J=8.6 \mathrm{~Hz}, 1 \mathrm{H}, \mathrm{Ar}-\mathrm{H}), 6.85$ (d, $J=8.1 \mathrm{~Hz}, 2 \mathrm{H}$, Ar-H), 6.60-6.24 (m, 2H, Ar-H), 5.09-4.62 (m, 2H, -O- $\left.\mathrm{CH}_{2}-\right)$, 3.72 $\left(\mathrm{s}, 3 \mathrm{H},-\mathrm{OCH}_{3}\right) \cdot{ }^{13} \mathrm{C} \mathrm{NMR}(75 \mathrm{MHz}, \mathrm{DMSO}) \delta 169.43$ (s, 14C), 164.73 (s, 18C), 159.64 (s, 11C), 158.04 (s, 6C), 157.08 (s, 16C), 148.40 (s, 9C), 144.35 (s, 19C), 134.56 (s, 20C), 134.32 (s, 23C), 130.68 (s, 2C), 130.46 (s, 4C), 129.32 (s, 21C, 25C), 129.29 (s, 22C, 24C), 127.62 (s, 13C), 127.40 (s, 3C), 126.75 (s, 8C), 119.13 (s, 15C), 114.32 (s, 1C, 5C), 105.83 (s, 12C), 102.47 (s, 10C), 66.88 (s, 17C), 55.45 (s, 7C). ESI-TOF, calcd for $\mathrm{C}_{25} \mathrm{H}_{20} \mathrm{~N}_{2} \mathrm{O}_{5}\left([\mathrm{M}+\mathrm{Na}]^{+}\right)$451.1372, found 451.1351. Anal. calcd for $\mathrm{C}_{25} \mathrm{H}_{20} \mathrm{~N}_{2} \mathrm{O}_{5}$ : C, 70.09; H, 4.71; N, 6.54; O, 18.67. Found: C, 69.58; H, 4.75; N, 6.61; O, 18.74 .

(Z)- $N^{\prime}$-(2-Fluorobenzylidene)-2-((3-(4-methoxyphenyl)-4-oxo-4Hchromen-7-yl)oxy)acetohydrazide (4b). White powder, yield 63\%; mp: $245.7-247.1{ }^{\circ} \mathrm{C}$; 95.3\% purity (HPLC); ${ }^{1} \mathrm{H}$ NMR (300 MHz, DMSO) $\delta 11.71(\mathrm{~s}, 1 \mathrm{H},-\mathrm{CH}=\mathrm{N}), 8.62-8.19(\mathrm{~m}, 1 \mathrm{H}, \mathrm{Ar}-\mathrm{H})$, $7.91(\mathrm{dt}, J=15.0,7.6 \mathrm{~Hz}, 1 \mathrm{H}, \mathrm{Ar}-\mathrm{H}), 7.76$ (s, 1H, N-NH), 7.55-7.39 (m, 1H, Ar-H), 7.35-7.22 (m, 2H, Ar-H), 7.21-7.13 (m, 2H, Ar-H), $7.02(\mathrm{t}, J=9.1 \mathrm{~Hz}, 1 \mathrm{H}, \mathrm{Ar}-\mathrm{H}), 6.84(\mathrm{~d}, J=8.0 \mathrm{~Hz}, 2 \mathrm{H}, \mathrm{Ar}-\mathrm{H}), 6.62-$ $6.22(\mathrm{~m}, 2 \mathrm{H}, \mathrm{Ar}-\mathrm{H}), 5.15-4.60\left(\mathrm{~m}, 2 \mathrm{H},-\mathrm{O}-\mathrm{CH}_{2}-\right), 3.71(\mathrm{~s}, 3 \mathrm{H}$, $-\mathrm{OCH}_{3}$ ). ${ }^{13} \mathrm{C}$ NMR (75 MHz, DMSO) $\delta 169.54$ (s, 14C), 164.86 (s, 18C), 161.96 (s, 11C), 160.31 (s, 6C), 157.05 (s, 25C), 149.08 (s, 16C), 145.26 (s, 9C), 141.19 (s, 19C), 137.13 (s, 23C), 132.38 (d, $=8.5 \mathrm{~Hz}, 21 \mathrm{C}), 126.90(\mathrm{~d}, J=15.3 \mathrm{~Hz}, 2 \mathrm{C}, 4 \mathrm{C}), 125.39$ (s, 13C), 122.11 (s, 3C), 121.97 (s, 22C), 119.14 (s, 15C), 116.40 (s, 8C, 20C), 116.53 (s, 24C), 114.31 (s, 1C, 5C), 105.81 (s, 12C), 102.48 (s, 10C), $65.12(\mathrm{~s}, 17 \mathrm{C}), 55.45(\mathrm{~s}, 7 \mathrm{C})$. ESI-TOF, calcd for $\mathrm{C}_{25} \mathrm{H}_{19} \mathrm{FN}_{2} \mathrm{O}_{5}\left([\mathrm{M}+\mathrm{Na}]^{+}\right) 469.1278$, found 469.1263. Anal. calcd for $\mathrm{C}_{25} \mathrm{H}_{19} \mathrm{FN}_{2} \mathrm{O}_{5}$ : C, 67.26; H, 4.29; F, 4.26; N, 6.28; O, 17.92. Found: C, 67.14; H, 4.34; F, 4.31; N, 6.35; O, 18.02.

(Z)- $N^{\prime}$-(3-Fluorobenzylidene)-2-((3-(4-methoxyphenyl)-4-oxo-4Hchromen-7-yl)oxy)acetohydrazide (4c). White powder, yield 73\%; mp: 220.1-223.9 ${ }^{\circ} \mathrm{C}$; 95.5\% purity (HPLC); ${ }^{1} \mathrm{H}$ NMR (300 $\mathrm{MHz}, \mathrm{DMSO}) \delta 11.69(\mathrm{~s}, 1 \mathrm{H},-\mathrm{CH}=\mathrm{N}), 8.39-7.98(\mathrm{~m}, 1 \mathrm{H}, \mathrm{Ar}-\mathrm{H})$, 7.72 (s, 1H, N-NH), 7.63-7.37 (m, 3H, Ar-H), 7.31-7.11 (m, 3H, Ar-H), 7.08-6.92 (m, 1H, Ar-H), 6.84 (d, $J=7.9 \mathrm{~Hz}, 2 \mathrm{H}, \mathrm{Ar}-\mathrm{H})$, $6.46(\mathrm{t}, J=21.5 \mathrm{~Hz}, 2 \mathrm{H}, \mathrm{Ar}-\mathrm{H}), 5.15-4.60\left(\mathrm{~m}, 2 \mathrm{H},-\mathrm{O}-\mathrm{CH}_{2}-\right)$, $3.71\left(\mathrm{~s}, 3 \mathrm{H},-\mathrm{OCH}_{3}\right)$. ESI-TOF, calcd for $\mathrm{C}_{25} \mathrm{H}_{19} \mathrm{FN}_{2} \mathrm{O}_{5}\left([\mathrm{M}+\mathrm{Na}]^{+}\right)$ 469.1278, found 469.1263. Anal. calcd for $\mathrm{C}_{25} \mathrm{H}_{19} \mathrm{FN}_{2} \mathrm{O}_{5}: \mathrm{C}$, 67.26; H, 4.29; F, 4.26; N, 6.28; O, 17.92. Found: C, 67.14; H, $4.34 ; \mathrm{F}, 4.31 ; \mathrm{N}, 6.35 ; \mathrm{O}, 18.02$.

(Z)- $N^{\prime}$-(4-Fluorobenzylidene)-2-((3-(4-methoxyphenyl)-4-oxo-4Hchromen-7-yl)oxy)acetohydrazide (4d). White powder, yield 67\%; mp: 261.9-263.1 ${ }^{\circ} \mathrm{C} ; 96.6 \%$ purity (HPLC); ${ }^{1} \mathrm{H}$ NMR (300 $\mathrm{MHz}, \mathrm{DMSO}) \delta 11.60(\mathrm{~s}, 1 \mathrm{H},-\mathrm{CH}=\mathrm{N}), 8.35-7.96(\mathrm{~m}, 1 \mathrm{H}, \mathrm{Ar}-\mathrm{H})$, 7.89 (s, 1H, N-NH), 7.75 (dt, $J=10.2,5.3 \mathrm{~Hz}, 2 \mathrm{H}, \mathrm{Ar}-\mathrm{H}), 7.25$ (ddd, $J=21.7,13.2,6.1 \mathrm{~Hz}, 4 \mathrm{H}, \mathrm{Ar}-\mathrm{H}), 7.00$ (s, 1H, Ar-H), 6.83 (s, 2H, Ar-H), 6.50 (d, J=16.2 Hz, 2H, Ar-H), 5.1-4.55 (m, 2H, -O$\left.\mathrm{CH}_{2}-\right)$, 3.70 (s, 3H, $-\mathrm{OCH}_{3}$ ). ESI-TOF, calcd for $\mathrm{C}_{25} \mathrm{H}_{19} \mathrm{FN}_{2} \mathrm{O}_{5}([\mathrm{M}$ $+\mathrm{Na}]^{+}$) 469.1278, found 469.1263. Anal. calcd for $\mathrm{C}_{25} \mathrm{H}_{19} \mathrm{FN}_{2} \mathrm{O}_{5}$ : C, 67.26; H, 4.29; F, 4.26; N, 6.28; O, 17.92. Found: C, 67.14; H, $4.34 ; \mathrm{F}, 4.31 ; \mathrm{N}, 6.35 ; \mathrm{O}, 18.02$.

(Z)- $N^{\prime}$-(3,4-Difluorobenzylidene)-2-((3-(4-methoxyphenyl)-4-oxo4H-chromen-7-yl)oxy)acetohydrazide (4e). White powder, yield 74\%; mp: $238.5-239.8{ }^{\circ} \mathrm{C} ; 96.3 \%$ purity (HPLC); ${ }^{1} \mathrm{H}$ NMR (300 MHz, DMSO) $\delta 11.70(\mathrm{~s}, 1 \mathrm{H},-\mathrm{CH}=\mathrm{N}), 8.34-7.94(\mathrm{~m}, 1 \mathrm{H}, \mathrm{Ar}-\mathrm{H})$,
7.90-7.64 (m, 2H, N-NH, Ar-H), 7.64-7.40 (m, 2H, Ar-H), 7.19 (d, $J=8.6 \mathrm{~Hz}, 2 \mathrm{H}, \mathrm{Ar}-\mathrm{H}), 7.01(\mathrm{t}, J=8.6 \mathrm{~Hz}, 1 \mathrm{H}, \mathrm{Ar}-\mathrm{H}), 6.84(\mathrm{~d}, J=$ $7.0 \mathrm{~Hz}, 2 \mathrm{H}, \mathrm{Ar}-\mathrm{H}), 6.45(\mathrm{t}, J=20.6 \mathrm{~Hz}, 2 \mathrm{H}, \mathrm{Ar}-\mathrm{H}), 5.15-4.60(\mathrm{~m}$, $\left.2 \mathrm{H},-\mathrm{O}-\mathrm{CH}_{2}-\right), 3.71\left(\mathrm{~s}, 3 \mathrm{H},-\mathrm{OCH}_{3}\right)$. ESI-TOF, calcd for $\mathrm{C}_{25} \mathrm{H}_{19} \mathrm{~F}_{2} \mathrm{~N}_{2} \mathrm{O}_{5}\left([\mathrm{M}+\mathrm{Na}]^{+}\right)$487.1184, found 487.1173. Anal. calcd for $\mathrm{C}_{25} \mathrm{H}_{19} \mathrm{FN}_{2} \mathrm{O}_{5}$ : C, 64.66; H, 3.91; F, 8.18; N, 6.03; O, 17.22. Found: C, 64.58; H, 3.99; F, 8.23; N, 6.11; O, 17.31.

(Z)- $N^{\prime}$-(2-Chlorobenzylidene)-2-((3-(4-methoxyphenyl)-4-oxo-4Hchromen-7-yl)oxy)acetohydrazide (4f). White powder, yield 75\%; mp: $216.2-217.3{ }^{\circ} \mathrm{C}$; $95.8 \%$ purity (HPLC); ${ }^{1} \mathrm{H}$ NMR $(300 \mathrm{MHz}$, DMSO) $\delta 11.82(\mathrm{~d}, J=20.7 \mathrm{~Hz}, 1 \mathrm{H},-\mathrm{CH}=\mathrm{N}), 8.78-8.32(\mathrm{~m}, 1 \mathrm{H}$, Ar-H), 8.00 (m, 2H, Ar-H), 7.78 (s, 1H, N-NH), 7.57-7.37 (m, 2H, Ar-H), 7.21 (dd, $J=7.0,1.4 \mathrm{~Hz}, 2 \mathrm{H}, \mathrm{Ar}-\mathrm{H}), 7.09-6.95$ (m, 1H, Ar$\mathrm{H}), 6.86$ (d, J=8.5 Hz, 2H, Ar-H), 6.59-6.31 (m, 2H, Ar-H), 5.20$4.48\left(\mathrm{~m}, 2 \mathrm{H},-\mathrm{O}-\mathrm{CH}_{2}-\right), 3.73\left(\mathrm{~s}, 3 \mathrm{H},-\mathrm{OCH}_{3}\right)$. ESI-TOF, calcd for $\mathrm{C}_{25} \mathrm{H}_{19} \mathrm{ClN}_{2} \mathrm{O}_{5}\left([\mathrm{M}+\mathrm{Na}]^{+}\right)$485.0982, found 485.0974. Anal. calcd for $\mathrm{C}_{25} \mathrm{H}_{19} \mathrm{ClN}_{2} \mathrm{O}_{5}$ : C, 64.87; H, 4.14; Cl, 7.66; N, 6.05; O, 17.28. Found: C, 64.69; H, 4.27; Cl, 7.74; N, 6.12; O, 17.32.

(Z)-N'-(3-Chlorobenzylidene)-2-((3-(4-methoxyphenyl)-4-oxo-4Hchromen-7-yl)oxy)acetohydrazide (4g). White powder, yield 78\%; mp: $231.8-232.6{ }^{\circ} \mathrm{C} ; 96.5 \%$ purity (HPLC); ${ }^{1} \mathrm{H}$ NMR (400 MHz, DMSO) $\delta 11.76(\mathrm{~s}, 1 \mathrm{H},-\mathrm{CH}=\mathrm{N}), 8.35-7.95(\mathrm{~m}, 1 \mathrm{H}, \mathrm{Ar}-\mathrm{H})$, 7.94 (s, 1H, N-NH), 7.85-7.72 (m, 1H, Ar-H), 7.68 (d, J=3.2 Hz, $1 \mathrm{H}, \mathrm{Ar}-\mathrm{H}$ ), 7.48 (dd, $J=13.8,7.9 \mathrm{~Hz}, 2 \mathrm{H}, \mathrm{Ar}-\mathrm{H}), 7.21$ (s, 2H, ArH), 7.04 (s, 1H, Ar-H), 6.87 (d, $J=22.1 \mathrm{~Hz}, 2 \mathrm{H}, \mathrm{Ar}-\mathrm{H}), 6.58-6.27$ (m, 2H, Ar-H), 5.20-4.60 (m, 2H, $-\mathrm{O}-\mathrm{CH}_{2}-$ ), 3.71 (s, 3H, $-\mathrm{OCH}_{3}$ ). ESI-TOF, calcd for $\mathrm{C}_{25} \mathrm{H}_{19} \mathrm{ClN}_{2} \mathrm{O}_{5}\left([\mathrm{M}+\mathrm{Na}]^{+}\right)$485.0982, found 485.0974. Anal. calcd for $\mathrm{C}_{25} \mathrm{H}_{19} \mathrm{ClN}_{2} \mathrm{O}_{5}$ : C, 64.87; H, 4.14; Cl, 7.66; N, 6.05; O, 17.28. Found: C, 64.69; H, 4.27; Cl, 7.74; N, 6.12; $\mathrm{O}, 17.32$.

(Z)- $\mathrm{N}^{\prime}$-(4-Chlorobenzylidene)-2-((3-(4-methoxyphenyl)-4-oxo-4Hchromen-7-yl)oxy)acetohydrazide (4h). White powder, yield 59\%; mp: 213.8-215.2 ${ }^{\circ} \mathrm{C} ; 97.3 \%$ purity (HPLC); ${ }^{1} \mathrm{H}$ NMR (300 $\mathrm{MHz}, \mathrm{DMSO}) \delta 11.67(\mathrm{~s}, 1 \mathrm{H},-\mathrm{CH}=\mathrm{N}), 8.35-8.10(\mathrm{~m}, 1 \mathrm{H}, \mathrm{Ar}-\mathrm{H})$, $7.74(\mathrm{dd}, J=8.5,4.8 \mathrm{~Hz}, 2 \mathrm{H}, \mathrm{Ar}-\mathrm{H}), 7.51(\mathrm{dd}, J=8.4,5.0 \mathrm{~Hz}, 2 \mathrm{H}$, $\mathrm{Ar}-\mathrm{H}), 7.21$ (d, $J=8.6 \mathrm{~Hz}, 2 \mathrm{H}, \mathrm{Ar}-\mathrm{H}), 7.08-6.75$ (m, $7.5 \mathrm{~Hz}, 3 \mathrm{H}, \mathrm{Ar}-$ $\mathrm{H})$, 6.59-6.27 (m, 2H, Ar-H), 5.15-4.55 (m, 2H, -O- $\left.\mathrm{CH}_{2}-\right), 3.72$ (s, $\left.3 \mathrm{H},-\mathrm{OCH}_{3}\right)$. ESI-TOF, calcd for $\mathrm{C}_{25} \mathrm{H}_{19} \mathrm{ClN}_{2} \mathrm{O}_{5}\left([\mathrm{M}+\mathrm{Na}]^{+}\right)$ 485.0982, found 485.0979. Anal. calcd for $\mathrm{C}_{25} \mathrm{H}_{19} \mathrm{ClN}_{2} \mathrm{O}_{5}: \mathrm{C}$, 64.87; H, 4.14; Cl, 7.66; N, 6.05; O, 17.28. Found: C, 64.69; H, 4.27; Cl, 7.74; N, 6.12; O, 17.32.

(Z)- $N^{\prime}$-(2,3-Dichlorobenzylidene)-2-((3-(4-methoxyphenyl)-4-oxo4H-chromen-7-yl)oxy)acetohydrazide (4i). White powder, yield 82\%; mp: $214.2-215.6{ }^{\circ} \mathrm{C} ; 96.5 \%$ purity (HPLC); ${ }^{1} \mathrm{H}$ NMR (300 MHz, DMSO) $\delta 11.89(\mathrm{~d}, J=20.9 \mathrm{~Hz}, 1 \mathrm{H},-\mathrm{CH}=\mathrm{N}), 8.80-8.35(\mathrm{~m}$, 1H, Ar-H), 8.04-7.87 (m, 1H, Ar-H), 7.86-7.59 (m, 2H, N-NH, Ar$\mathrm{H}), 7.43(\mathrm{td}, J=7.9,4.1 \mathrm{~Hz}, 1 \mathrm{H}, \mathrm{Ar}-\mathrm{H}), 7.19$ (d, $J=8.4 \mathrm{~Hz}, 2 \mathrm{H}, \mathrm{Ar}-$ H), 7.07-6.94 (m, 1H, Ar-H), 6.84 (d, $J=8.2 \mathrm{~Hz}, 2 \mathrm{H}, \mathrm{Ar}-\mathrm{H}), 6.46$ $(\mathrm{t}, J=23.2 \mathrm{~Hz}, 2 \mathrm{H}, \mathrm{Ar}-\mathrm{H}), 5.15-4.60\left(\mathrm{~m}, 2 \mathrm{H},-\mathrm{O}-\mathrm{CH}_{2}-\right), 3.71(\mathrm{~s}$, $\left.3 \mathrm{H},-\mathrm{OCH}_{3}\right)$. ESI-TOF, calcd for $\mathrm{C}_{25} \mathrm{H}_{18} \mathrm{Cl}_{2} \mathrm{~N}_{2} \mathrm{O}_{5}\left([\mathrm{M}+\mathrm{Na}]^{+}\right)$ 519.0593, found 519.0582. Anal. calcd for $\mathrm{C}_{25} \mathrm{H}_{18} \mathrm{Cl}_{2} \mathrm{~N}_{2} \mathrm{O}_{5}: \mathrm{C}$, 60.38; H, 3.65; Cl, 14.26; N, 5.63; O, 16.08. Found: C, 60.29; H, 3.69; Cl, 14.30; N, 5.74; O, 16.15 .

(Z)- $N^{\prime}$-(2,6-Dichlorobenzylidene)-2-((3-(4-methoxyphenyl)-4-oxo4H-chromen-7-yl)oxy)acetohydrazide (4j). White powder, yield 77\%; mp: $181.6-182.7{ }^{\circ} \mathrm{C}$; $95.6 \%$ purity (HPLC); ${ }^{1} \mathrm{H}$ NMR (300 $\mathrm{MHz}, \mathrm{DMSO}) \delta 11.86(\mathrm{~s}, 1 \mathrm{H},-\mathrm{CH}=\mathrm{N}), 8.55-8.22(\mathrm{~m}, 1 \mathrm{H}, \mathrm{Ar}-\mathrm{H})$, 
7.95-7.60 (m, 1H, N-NH), 7.55 (d, J = 7.9 Hz, 2H, Ar-H), 7.487.35 (m, 1H, Ar-H), 7.18 (d, J=8.0 Hz, 2H, Ar-H), 7.10-6.75 (m, $3 \mathrm{H}, \mathrm{Ar}-\mathrm{H}), 6.50$ (d, J=29.2 Hz, 2H, Ar-H), 5.05-4.60 (m, 2H, -O$\mathrm{CH}_{2}-$ ), 3.70 (s, 3H, $-\mathrm{OCH}_{3}$ ). ${ }^{13} \mathrm{C}$ NMR (75 MHz, DMSO) $\delta 169.71$ (s, 14C), 165.00 (s, 18C), 159.57 (s, 11C), 158.11 (s, 6C), 157.12 (s, 16C), 143.84 (s, 9C), 139.31 (s, 19C), 134.43 (s, 21C, 25C), 134.39 (s, 20C), 131.59 (s, 13C), 129.93 (s, 2C, 4C), 129.87 (s, 23C), 129.54 (s, 22C, 24C), 128.12 (s, 8C), 126.77 (s, 3C), 119.14 (s, 15C), 114.31 (s, 1C, 5C), 105.72 (s, 12C), 102.33 (s, 10C), 66.86 (s, 17C), 55.45 (s, 7C). ESI-TOF, calcd for $\mathrm{C}_{25} \mathrm{H}_{18} \mathrm{Cl}_{2} \mathrm{~N}_{2} \mathrm{O}_{5}\left([\mathrm{M}+\mathrm{Na}]^{+}\right)$ 519.0593, found 519.0582. Anal. calcd for $\mathrm{C}_{25} \mathrm{H}_{18} \mathrm{Cl}_{2} \mathrm{~N}_{2} \mathrm{O}_{5}: \mathrm{C}$, 60.38; H, 3.65; Cl, 14.26; N, 5.63; O, 16.08. Found: C, 60.29; H, 3.69; Cl, 14.30; N, 5.74; O, 16.15 .

(Z)- $N^{\prime}$-(3-Bromobenzylidene)-2-((3-(4-methoxyphenyl)-4-oxo-4Hchromen-7-yl)oxy)acetohydrazide (4k). White powder, yield 82\%; mp: $224.0-225.2{ }^{\circ} \mathrm{C}$; $97.8 \%$ purity (HPLC); ${ }^{1} \mathrm{H}$ NMR (300 MHz, DMSO) $\delta 11.69(\mathrm{~s}, 1 \mathrm{H},-\mathrm{CH}=\mathrm{N}), 8.30-7.95(\mathrm{~m}, 1 \mathrm{H}, \mathrm{Ar}-\mathrm{H})$, 7.90 (d, $J=9.7 \mathrm{~Hz}, 1 \mathrm{H}, \mathrm{Ar}-\mathrm{H}), 7.69$ (d, $J=7.7 \mathrm{~Hz}, 1 \mathrm{H}, \mathrm{Ar}-\mathrm{H}), 7.59$ (d, $J=6.6 \mathrm{~Hz}, 1 \mathrm{H}, \mathrm{Ar}-\mathrm{H}), 7.39$ (dd, $J=14.5,6.7 \mathrm{~Hz}, 1 \mathrm{H}, \mathrm{Ar}-\mathrm{H})$, 7.19 (d, $J=8.4 \mathrm{~Hz}, 2 \mathrm{H}, \mathrm{Ar}-\mathrm{H}), 6.99$ (d, $J=8.1 \mathrm{~Hz}, 1 \mathrm{H}, \mathrm{Ar}-\mathrm{H})$, $6.84(\mathrm{~s}, 2 \mathrm{H}, \mathrm{Ar}-\mathrm{H}), 6.56-6.22(\mathrm{~m}, 2 \mathrm{H}, \mathrm{Ar}-\mathrm{H}), 5.15-4.59(\mathrm{~m}, 2 \mathrm{H}$, $\left.-\mathrm{O}-\mathrm{CH}_{2}-\right), \quad 3.70\left(\mathrm{~s}, \quad 3 \mathrm{H}, \quad-\mathrm{OCH}_{3}\right)$. ESI-TOF, calcd for $\mathrm{C}_{25} \mathrm{H}_{19} \mathrm{BrN}_{2} \mathrm{O}_{5}\left([\mathrm{M}+\mathrm{Na}]^{+}\right)$529.0477, found 529.0438. Anal. calcd for $\mathrm{C}_{25} \mathrm{H}_{19} \mathrm{BrN}_{2} \mathrm{O}_{5}$ : C, 59.19; $\mathrm{H}, 3.77 ; \mathrm{Br}, 15.75 ; \mathrm{N}, 5.52 ; \mathrm{O}, 15.77$. Found: C, 59.10; H, 3.83; Br, 15.82; N, 5.59; O, 15.80.

(Z)- $N^{\prime}$-(3-Hydroxybenzylidene)-2-((3-(4-methoxyphenyl)-4-oxo4H-chromen-7-yl)oxy)acetohydrazide (41). White powder, yield 82\%; mp: $294.1-295.7{ }^{\circ} \mathrm{C}$; $95.2 \%$ purity (HPLC); ${ }^{1} \mathrm{H}$ NMR (400 $\mathrm{MHz}, \mathrm{DMSO}) \delta 11.59(\mathrm{~s}, 1 \mathrm{H},-\mathrm{CH}=\mathrm{N}), 8.25-7.90(\mathrm{~m}, 1 \mathrm{H}, \mathrm{Ar}-\mathrm{H})$, $7.68(\mathrm{~s}, 1 \mathrm{H}, \mathrm{N}-\mathrm{NH}), 7.28-6.95(\mathrm{~m}, 6 \mathrm{H}, \operatorname{Ar}-\mathrm{H}), 6.83(\mathrm{~d}, J=$ $8.1 \mathrm{~Hz}, 3 \mathrm{H}, \mathrm{Ar}-\mathrm{H}), 6.52$ (d, $J=25.9 \mathrm{~Hz}, 2 \mathrm{H}, \mathrm{Ar}-\mathrm{H}), 5.15-4.60(\mathrm{~m}$, $\left.2 \mathrm{H},-\mathrm{O}-\mathrm{CH}_{2}-\right), 3.72\left(\mathrm{~s}, 3 \mathrm{H},-\mathrm{OCH}_{3}\right) .{ }^{13} \mathrm{C} \mathrm{NMR}(100 \mathrm{MHz}, \mathrm{DMSO})$ $\delta 169.31$ (s, 14C), 164.66 (s, 18C), 158.14 (s, 14C), 158.10 (s, 6C), 157.08 (s, 24C), 148.44 (s, 9C), 144.54 (s, 19C), 135.83 (s, 20C), 135.66 (s, 22C), 130.35 (s, 2C, 4C), 128.09 (s, 13C), 126.74 (s, 3C), 119.33 (s, 8C), 118.85 (s, 21C), 118.02 (s, 23C), 117.76 (s, 14C), 114.32 (s, 25C, 1C, 5C), 113.23 (s), 113.12 (s), 105.81 (s, 12C), 102.82 (s, 10C), 66.87 (s, 17C), 55.45 (s, 7C). ESI-TOF, calcd for $\mathrm{C}_{25} \mathrm{H}_{20} \mathrm{~N}_{2} \mathrm{O}_{6}\left([\mathrm{M}+\mathrm{Na}]^{+}\right)$467.1321, found 467.1314. Anal. calcd for $\mathrm{C}_{25} \mathrm{H}_{20} \mathrm{~N}_{2} \mathrm{O}_{6}$ : C, 67.56; $\mathrm{H}, 4.54 ; \mathrm{N}, 6.30 ; \mathrm{O}, 21.60$. Found: $\mathrm{C}$, 67.47; H, 4.61; N, 6.39; O, 21.65.

(Z)-N'-(4-Hydroxybenzylidene)-2-((3-(4-methoxyphenyl)-4-oxo4H-chromen-7-yl)oxy)acetohydrazide (4m). White powder, yield 82\%; mp: $248.3-249.5{ }^{\circ} \mathrm{C}$; $95.3 \%$ purity (HPLC); ${ }^{1} \mathrm{H}$ NMR (300 $\mathrm{MHz}, \mathrm{DMSO}) \delta 11.38(\mathrm{~d}, J=8.6 \mathrm{~Hz}, 1 \mathrm{H},-\mathrm{CH}=\mathrm{N}), 10.01(\mathrm{~s}, 1 \mathrm{H}$, $-\mathrm{OH}), 8.25-7.85(\mathrm{~m}, 1 \mathrm{H}, \mathrm{Ar}-\mathrm{H}), 7.76(\mathrm{~s}, 1 \mathrm{H}, \mathrm{N}-\mathrm{NH}), 7.51$ (d, $J=$ $8.4 \mathrm{~Hz}, 2 \mathrm{H}, \mathrm{Ar}-\mathrm{H}), 7.19$ (dd, $J=8.8,2.6 \mathrm{~Hz}, 2 \mathrm{H}, \mathrm{Ar}-\mathrm{H}), 7.01(\mathrm{t}, J=$ 8.5 Hz, 1H, Ar-H), 6.89-6.73 (m, 4H, Ar-H), 6.54-6.25 (m, 2H, Ar$\mathrm{H})$, 5.10-4.55 (m, 2H, -O- $\left.\mathrm{CH}_{2}-\right)$, $3.70\left(\mathrm{~s}, 3 \mathrm{H},-\mathrm{OCH}_{3}\right)$. ESI-TOF, calcd for $\mathrm{C}_{25} \mathrm{H}_{20} \mathrm{~N}_{2} \mathrm{O}_{6}\left([\mathrm{M}+\mathrm{Na}]^{+}\right)$467.1321, found 467.1314. Anal. calcd for $\mathrm{C}_{25} \mathrm{H}_{20} \mathrm{~N}_{2} \mathrm{O}_{6}$ : C, 67.56; H, 4.54; N, 6.30; O, 21.60. Found: C, 67.47; H, 4.61; N, 6.39; O, 21.65.

(Z)- $N^{\prime}$-(4-Aminobenzylidene)-2-((3-(4-methoxyphenyl)-4-oxo-4Hchromen-7-yl)oxy)acetohydrazide (4n). Orange powder, yield 69\%; mp: $247.6-248.3{ }^{\circ} \mathrm{C}$; 95.4\% purity (HPLC); ${ }^{1} \mathrm{H}$ NMR $(300 \mathrm{MHz}$, DMSO) $\delta 11.23(\mathrm{~d}, J=5.6 \mathrm{~Hz}, 1 \mathrm{H},-\mathrm{CH}=\mathrm{N}), 8.14-7.78(\mathrm{~m}, 1 \mathrm{H}, \mathrm{Ar}-$ H), 7.75 (s, 1H, N-NH), 7.34 (d, $J=8.5 \mathrm{~Hz}, 2 \mathrm{H}, \mathrm{Ar}-\mathrm{H}), 7.17$ (dt, $J=$
14.1, 7.0 Hz, 2H, Ar-H), $7.00(\mathrm{t}, J=8.3 \mathrm{~Hz}, 1 \mathrm{H}, \mathrm{Ar}-\mathrm{H}), 6.82(\mathrm{t}, J=$ $10.8 \mathrm{~Hz}, 2 \mathrm{H}, \mathrm{Ar}-\mathrm{H}), 6.56$ (d, J=8.0 Hz, 2H, Ar-H), 6.47-6.28 (m, $2 \mathrm{H}$, $\mathrm{Ar}-\mathrm{H}), 5.61$ (d, $\left.J=9.2 \mathrm{~Hz}, 2 \mathrm{H},-\mathrm{NH}_{2}\right), 5.55-4.51$ (m, 2H, $-\mathrm{O}-\mathrm{CH}_{2}-$ ), $3.70\left(\mathrm{~s}, 3 \mathrm{H},-\mathrm{OCH}_{3}\right)$. ESI-TOF, calcd for $\mathrm{C}_{25} \mathrm{H}_{21} \mathrm{~N}_{3} \mathrm{O}_{5}\left([\mathrm{M}+\mathrm{Na}]^{+}\right)$ 466.1481, found 466.1473. Anal. calcd for $\mathrm{C}_{25} \mathrm{H}_{21} \mathrm{~N}_{3} \mathrm{O}_{5}: \mathrm{C}, 67.71 ; \mathrm{H}$, 4.77; N, 9.48; O, 18.04. Found: C, 67.65; H, 4.82; N, 9.53; O, 18.14.

(Z)-2-((3-(4-Methoxyphenyl)-4-oxo-4H-chromen-7-yl)oxy)- $N^{\prime}$-(2(trifluoromethyl)benzylidene)acetohydrazide (4o). White powder, yield 73\%; mp: 203.1-204.5 ${ }^{\circ} \mathrm{C}$; 96.7\% purity (HPLC); ${ }^{1} \mathrm{H}$ NMR (300 MHz, DMSO) $\delta 11.90(\mathrm{~d}, J=35.0 \mathrm{~Hz}, 1 \mathrm{H},-\mathrm{CH}=\mathrm{N})$, 8.75-8.32 (m, 1H, Ar-H), 8.19 (dd, $J=16.1,7.6 \mathrm{~Hz}, 1 \mathrm{H}, \mathrm{Ar}-\mathrm{H})$, 7.85-7.52 (m, 4H, N-NH, Ar-H), 7.19 (d, $J=7.3 \mathrm{~Hz}, 2 \mathrm{H}, \mathrm{Ar}-\mathrm{H})$, 7.09-6.91 (m, 1H, Ar-H), 6.84 (d, $J=7.5 \mathrm{~Hz}, 2 \mathrm{H}, \mathrm{Ar}-\mathrm{H}), 6.62-$ $6.22(\mathrm{~m}, 2 \mathrm{H}, \mathrm{Ar}-\mathrm{H}), 5.21-4.60\left(\mathrm{~m}, 2 \mathrm{H},-\mathrm{O}-\mathrm{CH}_{2}-\right), 3.70(\mathrm{~s}, 3 \mathrm{H}$, $\left.-\mathrm{OCH}_{3}\right)$. ESI-TOF, calcd for $\mathrm{C}_{26} \mathrm{H}_{19} \mathrm{~F}_{3} \mathrm{~N}_{2} \mathrm{O}_{5}\left([\mathrm{M}+\mathrm{Na}]^{+}\right)$519.1246, found 519.1209. Anal. calcd for $\mathrm{C}_{26} \mathrm{H}_{19} \mathrm{~F}_{3} \mathrm{~N}_{2} \mathrm{O}_{5}$ : C, 62.90; H, 3.86; F, 11.48; N, 5.64; O, 16.11. Found: C, 62.82; H, 3.94; F, 11.53; N, $5.72 ; \mathrm{O}, 16.24$.

(Z)-2-((3-(4-Methoxyphenyl)-4-oxo-4H-chromen-7-yl)oxy)- $N^{\prime}$-(4(trifluoromethyl)benzylidene)acetohydrazide (4p). White powder, yield 68\%; mp: $176.7-178.2{ }^{\circ} \mathrm{C}$; $97.5 \%$ purity (HPLC); ${ }^{1} \mathrm{H}$ NMR (300 MHz, DMSO) $\delta 11.79(\mathrm{~s}, 1 \mathrm{H},-\mathrm{CH}=\mathrm{N}), 8.43-8.05$ (m, 1H, Ar-H), 7.92 (d, $J=8.1 \mathrm{~Hz}, 2 \mathrm{H}, \mathrm{Ar}-\mathrm{H}), 7.78(\mathrm{t}, J=7.2 \mathrm{~Hz}$, $3 \mathrm{H}, \mathrm{N}-\mathrm{NH}, \mathrm{Ar}-\mathrm{H}), 7.19$ (dd, $J=8.7,2.1 \mathrm{~Hz}, 2 \mathrm{H}, \mathrm{Ar}-\mathrm{H}), 7.02(\mathrm{t}, J=$ $8.7 \mathrm{~Hz}, 1 \mathrm{H}, \mathrm{Ar}-\mathrm{H}), 6.84$ (d, $J=8.3 \mathrm{~Hz}, 2 \mathrm{H}, \mathrm{Ar}-\mathrm{H}), 6.61-6.29(\mathrm{~m}$, $2 \mathrm{H}, \mathrm{Ar}-\mathrm{H}), 5.17-4.61\left(\mathrm{~m}, 2 \mathrm{H},-\mathrm{O}-\mathrm{CH}_{2}-\right), 3.71\left(\mathrm{~s}, 3 \mathrm{H},-\mathrm{OCH}_{3}\right) \cdot{ }^{13} \mathrm{C}$ NMR (75 MHz, DMSO) $\delta 169.73$ (s, 14C), 165.08 (s, 18C), 159.79159.10 (m, 11C), 158.05 (s, 6C), 157.08 (s, 16C), 146.63 (s, 9C), 142.67 (s, 19C), 138.56 (s, 20C), 138.39 (s, 23C), 130.18 (s, 2C, 4C), 128.20 (s, 21C, 25C), 128.01 (s, 13C), 126.74 (s, 22C, 24C), 126.16 (d, $J=4.7 \mathrm{~Hz}, 3 \mathrm{C}), 125.46$ (s, $\left.\underline{\mathrm{CF}}_{3}\right), 123.66$ (s, 8C), 119.13 (s, 15C), 114.31 (s, 1C, 5C), 105.79 (s, 12C), 102.54 (s, 10C), 66.84 (s, 17C), 55.44 (s, 7C). ESI-TOF, calcd for $\mathrm{C}_{26} \mathrm{H}_{19} \mathrm{~F}_{3} \mathrm{~N}_{2} \mathrm{O}_{5}([\mathrm{M}+$ $\mathrm{Na}]^{+}$) 519.1246, found 519.1209. Anal. calcd for $\mathrm{C}_{26} \mathrm{H}_{19} \mathrm{~F}_{3} \mathrm{~N}_{2} \mathrm{O}_{5}$ : C, 62.90; H, 3.86; F, 11.48; N, 5.64; O, 16.11. Found: C, 62.82; H, $3.94 ; \mathrm{F}, 11.53 ; \mathrm{N}, 5.72 ; \mathrm{O}, 16.24$.

(Z)-2-((3-(4-Methoxyphenyl)-4-oxo-4H-chromen-7-yl)oxy)- $N^{\prime}$-(4methylbenzylidene)acetohydrazide (4q). White powder, yield 62\%; mp: 202.1-203.3 ${ }^{\circ} \mathrm{C} ; 96.2 \%$ purity (HPLC); ${ }^{1} \mathrm{H}$ NMR (300 $\mathrm{MHz}, \mathrm{DMSO}) \delta 11.52(\mathrm{~d}, J=6.4 \mathrm{~Hz}, 1 \mathrm{H},-\mathrm{CH}=\mathrm{N}), 8.32-7.9(\mathrm{~m}$, 1H, Ar-H), 7.74 (s, 1H, N-NH), 7.58 (d, J = 7.8 Hz, 2H, Ar-H), 7.35-7.10 (m, 4H, Ar-H), 7.01 (t, $J=8.6 \mathrm{~Hz}, 1 \mathrm{H}, \mathrm{Ar}-\mathrm{H}), 6.84$ (d, $J=7.6 \mathrm{~Hz}, 2 \mathrm{H}, \mathrm{Ar}-\mathrm{H}$ ), 6.45 (dd, $J=28.6,17.3 \mathrm{~Hz}, 2 \mathrm{H}, \mathrm{Ar}-\mathrm{H}), 5.17-$ $4.51\left(\mathrm{~m}, 2 \mathrm{H},-\mathrm{O}-\mathrm{CH}_{2}-\right), 3.71\left(\mathrm{~s}, 3 \mathrm{H},-\mathrm{OCH}_{3}\right), 2.32\left(\mathrm{~s}, 3 \mathrm{H},-\mathrm{CH}_{3}\right)$. ESI-TOF, calcd for $\mathrm{C}_{26} \mathrm{H}_{22} \mathrm{~N}_{2} \mathrm{O}_{5}\left([\mathrm{M}+\mathrm{Na}]^{+}\right)$465.1529, found 465.1513. Anal. calcd for $\mathrm{C}_{26} \mathrm{H}_{22} \mathrm{~N}_{2} \mathrm{O}_{5}$ : C, 70.58; $\mathrm{H}, 5.01 ; \mathrm{N}, 6.33$; O, 18.08. Found: C, 70.14; H, 5.16; N, 6.42; O, 18.14.

(Z)- $N^{\prime}$-(2-Methoxybenzylidene)-2-((3-(4-methoxyphenyl)-4-oxo4H-chromen-7-yl)oxy)acetohydrazide (4r). White powder, yield 86\%; mp: $218.5-219.9{ }^{\circ} \mathrm{C} ; 97.1 \%$ purity (HPLC); ${ }^{1} \mathrm{H}$ NMR (400 MHz, DMSO) $\delta 11.62(\mathrm{~d}, J=17.4 \mathrm{~Hz}, 1 \mathrm{H},-\mathrm{CH}=\mathrm{N}), 8.71-8.32(\mathrm{~m}$, 1H, Ar-H), 7.84 (ddd, $J=16.7,7.7,1.5 \mathrm{~Hz}, 2 \mathrm{H}, \mathrm{N}-\mathrm{NH}, \mathrm{Ar}-\mathrm{H}$ ), 7.47$7.34(\mathrm{~m}, 1 \mathrm{H}, \mathrm{Ar}-\mathrm{H}), 7.21$ (dd, $J=8.8,2.4 \mathrm{~Hz}, 2 \mathrm{H}, \mathrm{Ar}-\mathrm{H}), 7.09(\mathrm{t}, J=$ $9.1 \mathrm{~Hz}, 1 \mathrm{H}, \mathrm{Ar}-\mathrm{H}), 7.02$ (dt, $J=10.7,8.2 \mathrm{~Hz}, 2 \mathrm{H}, \mathrm{Ar}-\mathrm{H}), 6.86(\mathrm{~d}, J=$ 8.0 Hz, 2H, Ar-H), 6.60-6.27 (m, 2H, Ar-H), 5.15-4.55 (m, 2H, -O$\left.\mathrm{CH}_{2}-\right), 3.86\left(\mathrm{~d}, J=3.2 \mathrm{~Hz}, 3 \mathrm{H},-\mathrm{OCH}_{3}\right), 3.72\left(\mathrm{~s}, 3 \mathrm{H},-\mathrm{OCH}_{3}\right)$. ESITOF, calcd for $\mathrm{C}_{26} \mathrm{H}_{22} \mathrm{~N}_{2} \mathrm{O}_{6}\left([\mathrm{M}+\mathrm{Na}]^{+}\right)$481.1478, found 481.1463. 
Anal. calcd for $\mathrm{C}_{26} \mathrm{H}_{22} \mathrm{~N}_{2} \mathrm{O}_{6}$ : C, 68.11; H, 4.84; N, 6.11; O, 20.94 . Found: C, 68.02; H, 4.92; N, 6.23; O, 20.98.

$(Z)-N^{\prime}$-(4-Methoxybenzylidene)-2-((3-(4-methoxyphenyl)-4-oxo4H-chromen-7-yl)oxy)acetohydrazide (4s). White powder, yield 75\%; mp: $193.5-194.5{ }^{\circ} \mathrm{C}$; $95.6 \%$ purity (HPLC); ${ }^{1} \mathrm{H}$ NMR (400 MHz, DMSO) $\delta 11.52(\mathrm{~s}, 1 \mathrm{H},-\mathrm{CH}=\mathrm{N}), 8.29-7.95(\mathrm{~m}, 1 \mathrm{H}, \mathrm{Ar}-\mathrm{H})$, 7.75-7.56 (m, 2H, Ar-H), 7.21 (d, $J=7.5 \mathrm{~Hz}, 2 \mathrm{H}, \mathrm{Ar}-\mathrm{H}), 7.01$ (dd, $J=8.7,6.8 \mathrm{~Hz}, 3 \mathrm{H}, \mathrm{Ar}-\mathrm{H}), 6.85$ (s, 2H), 6.63-6.22 (m, 2H, Ar$\mathrm{H}), 5.12-4.59\left(\mathrm{~m}, 2 \mathrm{H},-\mathrm{O}-\mathrm{CH}_{2}-\right), 3.80\left(\mathrm{~d}, J=2.8 \mathrm{~Hz}, 3 \mathrm{H},-\mathrm{OCH}_{3}\right)$, $3.72\left(\mathrm{~s}, 3 \mathrm{H},-\mathrm{OCH}_{3}\right)$. ESI-TOF, calcd for $\mathrm{C}_{26} \mathrm{H}_{22} \mathrm{~N}_{2} \mathrm{O}_{6}\left([\mathrm{M}+\mathrm{Na}]^{+}\right)$ 481.1478, found 481.1463. Anal. calcd for $\mathrm{C}_{26} \mathrm{H}_{22} \mathrm{~N}_{2} \mathrm{O}_{6}$ : C, 68.11; H, 4.84; N, 6.11; O, 20.94. Found: C, 68.02; H, 4.92; N, 6.23; O, 20.98 .

$(Z)-N^{\prime}$-(3,4-Dimethoxybenzylidene)-2-((3-(4-methoxyphenyl)-4oxo-4H-chromen-7-yl)oxy)acetohydrazide (4t). White powder, yield 63\%; mp: $140.7-141.8{ }^{\circ} \mathrm{C} ; 96.7 \%$ purity (HPLC); ${ }^{1} \mathrm{H}$ NMR (400 MHz, DMSO) $\delta 11.52(\mathrm{~d}, J=20.7 \mathrm{~Hz}, 1 \mathrm{H},-\mathrm{CH}=\mathrm{N}), 8.28-$ $7.90(\mathrm{~m}, 1 \mathrm{H}, \mathrm{Ar}-\mathrm{H}), 7.73$ (s, 1H, Ar-H), 7.32 (dd, $J=9.1,1.6 \mathrm{~Hz}$, $1 \mathrm{H}, \mathrm{Ar}-\mathrm{H}$ ), 7.21 (dd, $J=8.4,2.6 \mathrm{~Hz}, 3 \mathrm{H}, \mathrm{Ar}-\mathrm{H}$ ), 7.03 (dd, $J=16.7$, $8.3 \mathrm{~Hz}, 2 \mathrm{H}, \mathrm{Ar}-\mathrm{H}), 6.86$ (d, $J=6.8 \mathrm{~Hz}, 2 \mathrm{H}, \mathrm{Ar}-\mathrm{H}), 6.59-6.31(\mathrm{~m}$, $2 \mathrm{H}, \mathrm{Ar}-\mathrm{H}$ ), $5.18-4.60$ (m, $\left.2 \mathrm{H},-\mathrm{O}-\mathrm{CH}_{2}-\right), 3.81$ (dd, $J=8.5,6.6 \mathrm{~Hz}$, $\left.6 \mathrm{H},-\mathrm{OCH}_{3}\right), 3.72\left(\mathrm{~s}, 3 \mathrm{H},-\mathrm{OCH}_{3}\right)$. ESI-TOF, calcd for $\mathrm{C}_{27} \mathrm{H}_{24} \mathrm{~N}_{2} \mathrm{O}_{7}$ $\left([\mathrm{M}+\mathrm{Na}]^{+}\right)$511.1584, found 511.1558. Anal. calcd for $\mathrm{C}_{27} \mathrm{H}_{24} \mathrm{~N}_{2} \mathrm{O}_{7}$ : C, 66.39; H, 4.95; N, 5.73; O, 22.93. Found: C, 66.24; H, 5.03; N, 5.86; O, 23.06.

(Z)- $N^{\prime}$-(4-Isopropylbenzylidene)-2-((3-(4-methoxyphenyl)-4-oxo4H-chromen-7-yl)oxy)acetohydrazide (4u). White powder, yield 86\%; mp: $198.2-199.6{ }^{\circ} \mathrm{C} ; 97.2 \%$ purity (HPLC); ${ }^{1} \mathrm{H}$ NMR (300 MHz, DMSO) $\delta 11.52(\mathrm{~d}, J=11.9 \mathrm{~Hz}, 1 \mathrm{H},-\mathrm{CH}=\mathrm{N}), 8.31-7.95(\mathrm{~m}$, 1H, Ar-H), 7.75 (s, 1H, N-NH), 7.61 (d, J=8.2 Hz, 2H, Ar-H), 7.30 (dd, $J=8.0,5.1 \mathrm{~Hz}, 2 \mathrm{H}, \mathrm{Ar}-\mathrm{H}), 7.19$ (dd, $J=8.8,2.5 \mathrm{~Hz}, 2 \mathrm{H}, \mathrm{Ar}-\mathrm{H}$ ), $7.02(\mathrm{t}, J=8.6 \mathrm{~Hz}, 1 \mathrm{H}, \mathrm{Ar}-\mathrm{H}), 6.84(\mathrm{~d}, J=8.1 \mathrm{~Hz}, 2 \mathrm{H}, \mathrm{Ar}-\mathrm{H}), 6.56-$ $6.30(\mathrm{~m}, 2 \mathrm{H}, \mathrm{Ar}-\mathrm{H}), 5.12-4.55\left(\mathrm{~m}, 2 \mathrm{H},-\mathrm{O}-\mathrm{CH}_{2}-\right), 3.71(\mathrm{~s}, 3 \mathrm{H}$, $\left.-\mathrm{OCH}_{3}\right), 2.90\left(\mathrm{~m}, 1 \mathrm{H},-\underline{\mathrm{CH}}\left(\mathrm{CH}_{3}\right)_{2}\right), 1.20(\mathrm{dd}, J=6.9,1.8 \mathrm{~Hz}, 6 \mathrm{H}$, $\left.-\mathrm{CH}\left(\underline{\mathrm{CH}_{3}}\right)_{2}\right)$. ESI-TOF, calcd for $\mathrm{C}_{28} \mathrm{H}_{26} \mathrm{~N}_{2} \mathrm{O}_{5}\left([\mathrm{M}+\mathrm{Na}]^{+}\right)$ 493.1842, found 493.1837. Anal. calcd for $\mathrm{C}_{28} \mathrm{H}_{26} \mathrm{~N}_{2} \mathrm{O}_{5}$ : C, 71.48; H, 5.57; N, 5.95; O, 17.00. Found: C, 71.31; H, 5.62; N, 5.995; O, 17.12.

$(Z)-N^{\prime}$-(4-(Benzyloxy)benzylidene)-2-((3-(4-methoxyphenyl)-4oxo-4H-chromen-7-yl)oxy)acetohydrazide (4v). White powder, yield 69\%; mp: $182.4-183.5{ }^{\circ} \mathrm{C} ; 97.2 \%$ purity (HPLC); ${ }^{1} \mathrm{H}$ NMR (300 MHz, DMSO) $\delta 11.46(\mathrm{~d}, J=8.5 \mathrm{~Hz}, 1 \mathrm{H},-\mathrm{CH}=\mathrm{N}), 8.30-7.90$ (m, 1H, Ar-H), 7.80 (d, J=8.4 Hz, 1H, N-NH), 7.63 (d, $J=8.3 \mathrm{~Hz}$, 2H, Ar-H), 7.38 (ddd, $J=19.5,13.1,6.8 \mathrm{~Hz}, 5 \mathrm{H}, \mathrm{Ar}-\mathrm{H}), 7.19$ (d, $J=$ $8.0 \mathrm{~Hz}, 2 \mathrm{H}, \mathrm{Ar}-\mathrm{H}$ ), 7.05 (dd, $J=15.8,7.5 \mathrm{~Hz}, 3 \mathrm{H}, \mathrm{Ar}-\mathrm{H}$ ), 6.85 (s, 2H, Ar-H), 6.58-6.22 (m, 2H, Ar-H), 5.14 (s, 2H, Ph-CH ${ }_{2}$ ), 5.10$4.55\left(\mathrm{~m}, 2 \mathrm{H},-\mathrm{O}-\mathrm{CH}_{2}-\right), 3.70\left(\mathrm{~s}, 3 \mathrm{H},-\mathrm{OCH}_{3}\right) .{ }^{13} \mathrm{C} \mathrm{NMR}(75 \mathrm{MHz}$, DMSO) $\delta 169.17$ (s, 14C), 164.43 (s, 18C), 160.48 (s, 11C), 160.26 (s, 23C), 148.21 (s, 6C), 144.14 (s, 16C), 137.21 (s, 9C), 129.24 (s, 19C), 128.99 (s, 27C), 128.94 (s, 2C, 4C, 21C, 25C), 128.42 (s, 29C, 31C), 128.25 (s, 13C), 127.31 (s, 28C, 32C), 127.23 (s, 31C), 115.62 (s, 20C, 3C), 114.32 (s, 1C, 5C, 22C, 24C), 105.80 (s, 8C, 12C), 102.86 (s, 15C), 102.45 (s, 10C), 69.81 (s, 26C), 66.89 (s, 17C), 55.45 (s, 7C). ESI-TOF, calcd for $\mathrm{C}_{32} \mathrm{H}_{26} \mathrm{~N}_{2} \mathrm{O}_{6}\left([\mathrm{M}+\mathrm{Na}]^{+}\right)$ 557.1791, found 557.1805. Anal. calcd for $\mathrm{C}_{32} \mathrm{H}_{26} \mathrm{~N}_{2} \mathrm{O}_{6}$ : C, 71.90; H, 4.90; N, 5.24; O, 17.96. Found: C, 71.83; H, 4.98; N, 5.31; O, 18.03 .

\section{Cell lines and culture conditions}

The cell lines used in this study were MCF-7, MDA-MB-231, H460, H1650, L02 and VERO. They were obtained from State Key Laboratory of Pharmaceutical Biotechnology, Nanjing University. MCF-7, MDA-MB-231, L02 and VERO cells were maintained in DMEM/high glucose supplemented with 10\% FBS, L-glutamine, and penicillin/streptomycin and incubated at $37{ }^{\circ} \mathrm{C}$ in humidified atmosphere containing $5 \% \mathrm{CO}_{2}$. $\mathrm{H} 460$ and H1650 cells were maintained in RPMI.1640 medium supplemented with $10 \%$ FBS and penicillin/streptomycin and incubated at $37{ }^{\circ} \mathrm{C}$ in humidified atmosphere containing $5 \% \mathrm{CO}_{2}$.

\section{Animals feeding}

Female nude mice (5-7 weeks old) were obtained from Model Animal Research Center of Nanjing University (Nanjing, China). Briefly, mice were fed with free access to pellet food and water in plastic cages at $21 \pm 2{ }^{\circ} \mathrm{C}$ and kept on a 12 hours light-dark cycle. All animal procedures were performed in accordance with the Guidelines for Care and Use of Laboratory Animals of Nanjing University and approved by the Animal Ethics Committee of the Ministry of Science and Technology of China (2006). All efforts were made to minimize animal suffering and to reduce the number of animals used.

\section{EGFR kinase phosphorylation assay}

The assays were carried out as described previously. ${ }^{3,28}$ Phosphorylation assays were performed in a final volume of $20 \mu \mathrm{L}$ containing $8 \mathrm{mM}$ MOPS (pH 7.0), $0.2 \mathrm{mM}$ EDTA, $10 \mathrm{mM} \mathrm{MnCl}_{2}$, $200 \mu \mathrm{M}$ substrate peptide, $0.25 \mathrm{mM}$ DTT, $0.1 \mathrm{mg} \mathrm{mL}^{-1} \mathrm{BSA}, 10$ ng of wild-type EGFR kinase (catalogue no. 40187, BPS Bioscience), $10 \mathrm{mM}$ magnesium acetate, $100 \mu \mathrm{M} \gamma-\left[{ }^{32} \mathrm{P}\right] \mathrm{ATP}$, and inhibitors or DMSO control $(1.25 \% \mathrm{v} / \mathrm{v})$. For $\mathrm{IC}_{50}$ curves with the wild-type enzyme, the following concentrations of the compounds were tested in triplicate: 150, 100, 50, 25, 15, 10, 7.5, 5 , and $2.5 \mathrm{nM}$. Reactions were started by the addition of the magnesium acetate/ATP mixture. After 30 minutes incubation at $30{ }^{\circ} \mathrm{C}, 5 \mu \mathrm{L}$ of each reaction was spotted on phosphocellulose P81 paper (Whatman). The P81 paper was then washed 5 times with $50 \mathrm{mM}$ phosphoric acid for 15 minutes, dried, and exposed to a phosphorimager screen (Storm, GE Healthcare), which was scanned and densitometrically analyzed the next day. The sequence of the substrate peptide was derived from phospholipase $\mathrm{C}-\gamma 1$. The $\mathrm{IC}_{50}$ values were calculated using nonlinear regression with normalized dose response fit using Prism GraphPad software.

\section{Anti-proliferation assay}

The anti-proliferation activity of the prepared compounds against four cancer cell lines, MCF-7, MDA-MB-231, H460, H1650 and two normal cell lines, L02 and VERO were evaluated as described elsewhere. ${ }^{29}$ Four kinds of cancer cell lines and two normal cell lines were plated in 96-well plates at the appropriate density $\left(2.0 \times 10^{3}\right.$ cells per well) with maintained in DMEM (or 1640 medium) with $10 \%$ FBS and cultivated for 12 hours at $37{ }^{\circ} \mathrm{C}, 5 \% \mathrm{CO}_{2}$ atmosphere. All cells treated with different 
concentrations $(0,0.1,1,10$ and $100 \mu \mathrm{M})$ of each compound with formononetin and lapatinib as positive references. After 24 hours, $20 \mu \mathrm{L}$ PBS containing of MTT solution $\left(2.5 \mathrm{mg} \mathrm{mL}^{-1}\right)$ was added to each well and incubated for a further 4 hours. Then $150 \mu \mathrm{L}$ of DMSO was added to each well to dissolve purple crystal. The plates were shaken to ensure the completion solubility for 10 minutes at room temperature. The values of absorbance were recorded on ELISA reader (ELx800, BioTek, USA) at a wavelength of $570 \mathrm{~nm}$. All experiments were performed in three replicate wells for each concentration of all compounds including formononetin, and all assay experiments were carried out three times. The $\mathrm{IC}_{50}$ values defined as the concentrations that cause a $50 \%$ loss of cell viability were calculated by Origin 7.5 and exhibited in Table 3 .

\section{Apoptosis analysis by flow cytometry}

Cell apoptosis assay of compound $\mathbf{4 v}$ for MDA-MB-231 cell was carried out by Annexin V/PI assays and monitored by flow cytometry. Briefly, $5 \times 10^{3}$ cells per well were seeded in 6-well plates for 12 hours and then treated with $\mathbf{4 v}(0,2,4$ and $8 \mu \mathrm{M})$ for 24 hours or treated with $4 \mu \mathrm{M} \mathbf{4 v}$ for $0,12,24$ and 36 hours. Next, cells were collected and washed twice with PBS and then centrifuged to obtain sedimentation. $500 \mu \mathrm{L} 1 \times$ binding buffer (10 mM HEPES, PH 7.4, $140 \mathrm{mM} \mathrm{NaOH,} 2.5 \mathrm{mM} \mathrm{CaCl}_{2}$ ) was added to each EP tube to make cells resuspended and stained with $5 \mu \mathrm{L}$ of Annexin V-FITC and $5 \mu \mathrm{L}$ of PI for 30 minutes at room temperature in the dark. Apoptotic cells were quantified using a BD Accuri C6 Flowjo Cytometer (BD, USA). Statistical analysis was done using Flowjo 7.6.1 software.

\section{Mitochondrial membrane potential staining}

JC-1 is an ideal fluorescent probe which is widely used in the detection of mitochondrial membrane potential $\left(\Delta \Psi_{\mathrm{m}}\right)$. According to the requirements, MDA-MB-231 cells were cultured in 6-well plates $\left(5 \times 10^{3}\right.$ cells per well) for 12 hours at $37{ }^{\circ} \mathrm{C}, 5 \% \mathrm{CO}_{2}$ atmosphere and then treated with compound $4 \mathbf{v}$ $(0,2$ and $4 \mu \mathrm{M})$ for 12 hours and with positive control drug, CCCP in another well for 30 minutes at $37^{\circ} \mathrm{C}$. Cell in all wells were collected and rinsed with PBS. Then $500 \mu \mathrm{L}$ JC-1 staining solution $(5 \times)$ was added to each EP tube and incubated at $37{ }^{\circ} \mathrm{C}$ for 20 minutes. Finally, cells were washed twice with JC-1 staining solution $(1 \times)$ and then resuspended to detect by BD Accuri C6 Flowjo Cytometer and Olympus confocal microscope, and data was analyzed using FV-10-ASW 1.7 viewer.

\section{Cell cycle arrested analysis by flow cytometry}

After incubation in 6-well plates $\left(5 \times 10^{3}\right.$ cells per well), MDAMB-231 cells were treated with compound $\mathbf{4 v}(0,2,4$ and 8 $\mu \mathrm{M})$ for 24 hours or treated with $4 \mu \mathrm{M} 4 \mathbf{v}$ for 0,24 and 36 hours. After that, cells were collected and washed twice with PBS and then fixed in $70 \%$ ethanol at $4{ }^{\circ} \mathrm{C}$ for at least 2 hours. Next, cells were resuspended in PBS with $0.1 \mathrm{mg} \mathrm{mL}^{-1}$ RNase A and $5 \mathrm{mg}$ $\mathrm{mL}^{-1}$ propidium iodide (PI) in the dark condition. The measure was performed by BD Accuri C6 Flowjo Cytometer (BD, USA). The date of cells in the G1, S and G2/M phases of the cell cycle were counted using the Flowjo 7.6.1 software excluding cell debris.

\section{Wound-healing assay}

MDA-MB-231 cells were seeded in a tissue culture 6-well plate at an initial density of $2 \times 10^{5}$ cells per $\mathrm{cm}^{2}$ overnight. A micropipette tip was used to create a wound in the monolayer by scraping after cells seeding and incubation for 24 hours. Identical cell-free space was observed by phase-contrast microscopy (NIKON, Japan) and digital images were taken by cells at 0,24 and 48 hours. Subsequently, the NIH Image J image analysis software was used to outline the wound areas and analysis quantifies the reduced cell-free space, $n=3$.

\section{Western blot analysis}

Total proteins were extracted from MDA-MB-231 cells which were treated with compound $\mathbf{4 v}$ at different concentrations $(0,2,4$ and $8 \mu \mathrm{M})$. Cells obtained were lysed in RIPA lysis buffer containing protease inhibitor phenylmethanesulfonyl fluoride (PMSF, PMSF $:$ RIPA = $1: 100$ ) on ice for 20-30 minutes. Protein content was measured using a Pierce BCA protein assay kit. Protein samples were separated by sodium dodecyl sulphatepolyacrylamide gel electrophoresis (SDS-PAGE) and then transferred onto polyvinylidene difluoride (PVDF) membranes which were blocked with 5\% non-fat-milk for 1 hour. All membranes were separated and incubated with primary antibodies including EGFR (rabbit polyclonal IgG, 1 : 1000 dilution), p-EGFR (rabbit polyclonal IgG, 1 : 1000 dilution), ERK (rabbit polyclonal IgG, 1 : 500 dilution), p-ERK (rabbit polyclonal IgG, $1: 500$ dilution), Akt (rabbit polyclonal IgG, 1 : 500 dilution), p-Akt (rabbit polyclonal IgG, $1: 500$ dilution), GAPDH (rabbit polyclonal IgG, $1: 1000$ dilution), CDK4 (rabbit polyclonal IgG, $1: 500$ dilution), Cyclin A (rabbit polyclonal IgG, 1:500 dilution), Cyclin D1 (rabbit polyclonal IgG, 1 : 500 dilution), $\beta$-actin (rabbit polyclonal IgG, 1 : 500 dilution), Bax (rabbit polyclonal IgG, 1 : 500 dilution), Bcl2 (rabbit polyclonal IgG, 1 : 500 dilution), cleaved caspase-3 (rabbit polyclonal IgG, 1:500 dilution), cleaved-PARP (mouse monoclonal IgG, 1:600 dilution), cytochrome c (rabbit polyclonal IgG, $1: 500$ dilution), $\beta$-catenin (rabbit polyclonal IgG, $1: 500$ dilution) and Axin-2 (rabbit polyclonal IgG, $1: 1000$ dilution) at $4{ }^{\circ} \mathrm{C}$ shaking overnight. After the membrane was washed three times with tris-buffered saline buffer, HRP-conjugated secondary antibody (diluted 1:50 000) was used at room temperature. Detection was performed by an enhanced chemiluminescent reagent (Thermo Fisher Scientific, USA) according to the manufacturer's instructions. Bands were then recorded by a digital camera (Tanon 5200, Tanon, China). Finally, the results were analyzed with Image J Software (National Institutes of Health, BetheSEMa, Maryland, USA), and all the targeted protein were normalized to GAPDH or $\beta$-actin.

\section{Transplantation of MDA-MB-231 cells into nude mice}

Cultured MDA-MB-231 cells were washed with and resuspended in ice-cold PBS. Portions of the suspension $\left(6 \times 10^{6}\right.$ cells in 0.1 $\mathrm{mL}$ ) were injected into the right flanks of female nu/nu mice. Two weeks after the injection, the mice bearing tumors (an 
average size of $\left.90 \mathrm{~mm}^{3}\right)$ were distributed into 3 groups $(n=8$ mice per group) according to tumor volumes. $4 \mathbf{v}\left(5 \mathrm{mg} \mathrm{kg}^{-1}\right)$ and lapatinib (5 $\mathrm{mg} \mathrm{kg}^{-1}$ ) were dissolved in olive oil and administered once every two days for 11 times by intraperitoneal injection. Vehicle (olive oil)-treated group was included as control. Body weight and tumor volumes were measured and recorded every two days. Long diameter $(L)$ and short diameter $(S)$ of a tumor were measured with a vernier caliper and the tumor volume was calculated using the following formula: $L \times$ $(S)^{2} / 2$. Twenty-one days after injection, the mice were killed and tumors were separated. Tumor weight was measured and tumor sections were fixed in paraformaldehyde. The rest of the sections were frozen in liquid nitrogen and stored at $-80{ }^{\circ} \mathrm{C}$.

\section{Data and statistical analysis}

All experiments were repeated at least three times. Data are presented as mean \pm S.E.M. and statistical comparisons between the treated and untreated groups were performed using one-way ANOVA using GraphPad PRISM5 (Graphpad Inc., La Jolla, USA). $P$-Values of $<0.05$ were considered statistically significant; $P$-values of $<0.01$ were considered statistically very significant.

\section{Conclusion}

In this study, a series of novel formononetin derivatives targeting EGFR kinase were designed, synthesized and evaluated for their potential anti-proliferation activities against human breast and lung cancer cell lines. Among them, compound $\mathbf{4 v}$ $\left(\mathrm{IC}_{50}=14.5 \mathrm{nM}\right)$ showed potent EGFR inhibitory activity which was almost comparable to that of gefitinib $\left(\mathrm{IC}_{50}=6.2 \mathrm{nM}\right)$ and lapatinib $\left(\mathrm{IC}_{50}=5.6 \mathrm{nM}\right)$. For in vitro anti-proliferation activities, $\mathbf{4 v}$ exhibited potent inhibitory activity against MDA-MB-231 cell line $\left(\mathrm{IC}_{50}=5.44 \pm 1.28 \mu \mathrm{M}\right)$ which was also comparable to lapatinib $\left(\mathrm{IC}_{50}=2.48 \pm 1.04 \mu \mathrm{M}\right)$ but much better than gefitinib $\left(\mathrm{IC}_{50}=12.5 \pm 2.13 \mu \mathrm{M}\right)$ and formononetin $\left(\mathrm{IC}_{50}=26.6 \pm 2.84\right.$ $\mu \mathrm{M}$ ) itself. The structure-activity relationship (SAR) analyzed by molecular docking showing that $\mathbf{4 v}$ could bind well to the active site of EGFR as lapatinib. Flow cytometry analysis and mitochondrial membrane potential staining results demonstrated that $\mathbf{4 v}$ could effectively cause loss of mitochondrial membrane potential and then induce apoptosis on MDA-MB-231 cells, but had no significant influence on cell cycle distribution. Western blot results further confirmed that $\mathbf{4 v}$ inhibited MDA-MB-231 cell proliferation by blocking EGFR downstream Ras/Raf/MEK/ ERK signaling pathway and induced MDA-MB-231 cell apoptosis by regulating EGFR/PI3K/Akt/Bad pathway. In addition, $\mathbf{4 v}$ could also effectively inhibit migration of MDA-MB-231 cells involving to Wnt signaling pathway. The preliminary in vivo anti-tumor results demonstrated the effectiveness of $\mathbf{4 v}$ in tumor chemotherapy in mice and indicated its possibility as a new EGFR inhibitor in curing MDA-MB-231 malignant tumor.

\section{Conflicts of interest}

The authors declare no conflict of interest.

\section{Abbreviations}

CADD Computer assist drug design

CCCP Carbonylcyanidem-chlorophen-ylhydrazone

EGF Epidermal growth factor

EGFR Epidermal growth factor receptor

ESI- Electrospray ionization-mass spectrometry

MS

HER2 Human epidermal growth factor receptor-2

HEPES 4-(2-Hydroxyethyl)-1-piperazineethanesulfonic acid

MAPK Mitogen-activated protein kinase

MTT 3-(4,5-Dimethylthiazol-2-yl)-2,5-diphenyltetrazolium bromide

NSCLC Non-small-cell carcinoma

PARP Poly-ADP ribose polymerase

PI Propidium iodide

SAR Structure-activity relationship

TLC Thin layer chromatography

UV Ultraviolet

\section{Acknowledgements}

The authors are grateful to the Program for Changjiang Scholars and Innovative Research Team in University (IRT_14R27), the National Natural Science Foundation of China (31470384, 31171161, and 31670298), and the Fundamental Research Funds for the Central Universities (020814380002).

\section{Notes and references}

1 A. Olayioye, R. M. Neve and N. E. Hynes, EMBO J., 2000, 17, 3159-3167.

2 I. Okamoto, FEBS J., 2010, 277, 309-315.

3 M. M. Hamed, S. S. Darwish, J. Herrmann, A. H. Abadi and M. Engel, J. Med. Chem., 2017, 60, 2853-2868.

4 Y. Yamanaka, H. Friess, M. Kobrin, M. Buchler, H. Beger and M. Korc, Anticancer Res., 1992, 13, 565-569.

5 J. M. Rae and M. E. Lippman, Breast Cancer Res. Treat., 2004, 83, 99-107.

6 R. E. Sobol, R. W. Astarita, C. Hofeditz, H. Masui, R. Fairshter, I. Royston and J. Mendelsohn, J. Natl. Cancer Inst., 1987, 79, 403-407.

7 S. Balakrishnan, S. Mukherjee, S. Das, F. A. Bhat, P. Raja Singh, C. R. Patra and J. Arunakaran, Cell Biochem. Funct., 2017, 35, 217-231.

8 K. Takasawa, A. Takasawa, M. Osanai, T. Aoyama, Y. Ono, T. Kono, Y. Hirohashi, M. Murata and N. Sawada, Cancer Lett., 2017, 403, 66-73.

9 A. Sgambato, F. Casaluce, P. Maione, A. Rossi, E. Rossi, A. Napolitano, G. Palazzlol, M. A. Bareschion, C. Schettino, P. C. Sacco, F. Ciadiello and C. Gridelli, Curr. Med. Chem., 2012, 19, 3337-3352.

10 K. Manupati, N. R. Dhoke, T. Debnath, R. Yeeravalli, K. Goguloth, S. Saeidpour, U. C. De, S. Debnath and A. Das, FEBS J., 2017, 284, 1830-1854. 
11 M. J. Duffy, P. M. Mcgowan and J. Crown, Int. J. Cancer, 2012, 131, 2471-2477.

12 D. Zhang, A. M. Tari, U. Akar, B. K. Arun, T. A. LaFortune, R. Nieves-Alicea, G. N. Hortobagyi and N. T. Ueno, Mol. Cancer Ther., 2010, 9, 3090-3099.

13 O. Lapčik, M. Hill, I. Černý, J. Lachman, N. Al-Maharik, H. Adlercreutz and R. Hampl, Plant Sci., 1999, 148, 111-119.

14 L. Hutabarat, H. Greenfield and M. Mulholland, J. Chromatogr. A, 2000, 886, 55-63.

15 X. Y. Wu, H. Xu, Z. F. Wu, C. Chen, J. Y. Liu, G. N. Wu, X. Q. Yao, F. K. Liu, G. Li and L. Shen, Oncotarget, 2015, 6, 44563-44578.

16 X. Yu, W. Wang and M. Yang, Food Chem., 2007, 104, 715720.

17 T. Fukai, A. Marumo, K. Kaitou, T. Kanda, S. Terada and T. Nomura, Life Sci., 2002, 71, 1449-1463.

18 Y. Ungar, O. F. Osundahunsi and E. Shimoni, J. Agric. Food Chem., 2003, 51, 4394-4399.

19 S. Sato, J. Takeo, C. Aoyama and H. Kawahara, Bioorg. Med. Chem., 2007, 15, 3445-3449.

20 Z. N. Ji, W. Zhao, G. Liao, R. Choi, C. K. Lo, T. T. X. Dong and K. W. K. Tsim, Gynecol. Endocrinol., 2006, 22, 578-584.
21 S. Medjakovic and A. Jungbauer, J. Steroid Biochem., 2008, 108, 171-177.

22 Y. M. Jin, T. M. Xu, Y. H. Zhao, Y. C. Wang and M. H. Cui, Tumor Biol., 2014, 35, 2279-2284.

23 D. J. Fu, L. Zhang, J. Song, R. W. Mao, R. H. Zhao, Y. C. Liu, Y. H. Hou, J. H. Li, J. J. Yang, C. Y. Jin, P. Li, X. L. Zi, H. M. Liu, S. Y. Zhang and Y. B. Zhang, Eur. J. Med. Chem., 2016, 127, 87-99.

24 Y. Q. Li, F. Yang, L. Wang, Z. Cao, T. J. Han, Z. A. Duan, Z. Li and W. J. Zhao, Eur. J. Med. Chem., 2016, 112, 196-208.

25 J. Ren, H. J. Xu, H. Cheng, W. Q. Xin, X. Chen and K. Hu, Eur. J. Med. Chem., 2012, 54, 175-187.

26 P. V. M. D. Alan, Cancer, 2005, 103, 2435-2446.

27 X. J. Zhu, Y. Shi, J. Peng, C. S. Guo, N. N. Shan, P. Qin, X. B. Ji and M. Hou, Blood, 2009, 114, 5362-5367.

28 Y. G. Zheng, J. Su, C. Y. Gao, P. Jiang, L. An, Y. S. Xue, J. Gao and Y. Liu, Eur. J. Med. Chem., 2017, 130, 393-405.

29 H. Y. Lin, Z. K. Li, L. F. Bai, S. K. Baloch, F. Wang, H. Y. Qiu, X. Wang, J. L. Qi, R. W. Yang, X. M. Wang and Y. H. Yang, Biochem. Pharmacol., 2015, 96, 93-106. 